\title{
Medications Development for Treatment of Opioid Use Disorder
}

\author{
E. Andrew Townsend, S. Stevens Negus, and Matthew L. Banks \\ Department of Pharmacology and Toxicology, Virginia Commonwealth University, Richmond, \\ Virginia 23298, USA \\ Correspondence: mbanks7@vcu.edu
}

This review describes methods for preclinical evaluation of candidate medications to treat opioid use disorder (OUD). The review is founded on the propositions that (1) drug selfadministration procedures provide the most direct method for assessment of medication effectiveness, (2) procedures that assess choice between opioid and nondrug reinforcers are especially useful, and (3) states of opioid dependence and withdrawal profoundly influence both opioid reinforcement and effects of candidate medications. Effects of opioid medications and vaccines on opioid choice in nondependent and opioid-dependent subjects are reviewed. Various nonopioid medications have also been examined, but none yet have been identified that safely and reliably reduce opioid choice. Future research will focus on (1) strategies for increasing safety and/or effectiveness of opioid medications (e.g., G-proteinbiased $\mu$-opioid agonists), and (2) continued development of nonopioid medications (e.g., clonidine) that might serve as adjunctive agents to current opioid medications.

$\mathrm{O}$ pioid use disorder (OUD) is a type of substance use disorder in which the abused substance is a $\mu$-opioid receptor (MOR) agonist (American Psychiatric Association 2013). In the United States, OUD and the related crisis of opioid overdose deaths has been fueled during the last 30 years by successive waves of different MOR agonists beginning with prescription opioid analgesics (e.g., oxycodone formulations) followed next by a surge in heroin and then most recently by synthetic opioids that include fentanyl and a host of fentanyl analogs (Ciccarone 2019; Lyden and Binswanger 2019). The abuse of heroin and synthetic opioids is also a growing problem in other parts of the world (Zawilska 2017; Karila et al. 2019). Currently approved pharmacotherapies for OUD in the United States include an array of opioid receptor ligands (naltrexone, buprenorphine, methadone) as well as medications for the symptomatic relief of some opioid withdrawal signs (e.g., the $\alpha_{2}$-adrenergic agonist clonidine) (Gonzalez et al. 2004; Rahimi-Movaghar et al. 2018). However, use of these medications is constrained by a variety of factors that include a dearth of treatment facilities, poor compliance with opioid antagonists, abuse liability of opioid agonists, and limitations in effectiveness of symptomatic treatments like clonidine to prevent relapse. In view of the scope of OUD and the constraints on use of existing treatments, the development of new, safer, and more effective

Editors: R. Christopher Pierce, Ellen M. Unterwald, and Paul J. Kenny

Additional Perspectives on Addiction available at www.perspectivesinmedicine.org

Copyright $\odot 2021$ Cold Spring Harbor Laboratory Press; all rights reserved; doi: 10.1101/cshperspect.a039263

Cite this article as Cold Spring Harb Perspect Med 2021;11:a039263 
E.A. Townsend et al.

medications remains a priority in substance use disorder research (Banks et al. 2019; Rasmussen et al. 2019). This review will focus on preclinical methods used in medications development for OUD, and the perspective of this review is founded on three related propositions:

1. Drug self-administration procedures provide the most direct measure of abuse-related reinforcing effects of opioids and the most important experimental tool for evaluation of candidate medications;

2. drug choice procedures constitute a subset of drug self-administration procedures in which subjects choose between drug and nondrug reinforcers, and these choice procedures may be especially useful in evaluation of medications for OUD; and

3. states of opioid dependence and withdrawal are key determinants of both opioid self-administration and of medication effects on opioid self-administration.

The remainder of this review will briefly discuss evidence for each of these propositions before proceeding to a review of medication effects on opioid choice under various conditions of opioid dependence and withdrawal. The work will conclude with a consideration of future directions.

\section{EXPERIMENTAL STRATEGIES FOR MEDICATION DEVELOPMENT}

Substance use disorder is a mental health disorder of behavior characterized by excessive drug use at the expense of more adaptive behaviors maintained by nondrug alternative reinforcers (Heyman 2009; Ahmed 2010; Banks and Negus 2012). The twin goals of treatment are to reduce drug use and promote reallocation of behavior to more adaptive activities. Determinants of drug-taking behavior can be directly studied in the laboratory using drug self-administration procedures. In these procedures, delivery of a drug dose (e.g., an intravenous dose of heroin) to an experimental subject (e.g., a rat, nonhuman primate, or human) is made contingent on the performance of some behavior (e.g., pressing an operant response lever) (Young and Herling 1986; Katz 1989; Caine et al. 1999). Under these general conditions, common drugs of abuse typically maintain rates of responding above those maintained by vehicle, and drug self-administration procedures have been used for decades to predict the abuse liability of opioids and other drugs (Johanson and Balster 1978; Ator and Griffiths 2003; O’Connor et al. 2011).

Drug self-administration procedures have also been used to evaluate candidate medications for the treatment of drug abuse (Mello and Negus 1996; Haney and Spealman 2008; Czoty et al. 2016; Banks and Negus 2017a). In these types of studies, self-administration of the target drug of abuse is established, and candidate medications are screened for their effectiveness to decrease drug self-administration. These experiments are guided by the general premise that medications that decrease preclinical drug self-administration are more likely to serve as promising substance use disorder treatments than medications that do not alter or that increase drug self-administration. However, interpretation of these experiments can be complicated by at least two factors.

First, candidate medications can reduce drug self-administration not only by reducing sensitivity to the abused opioid, but also by producing nonselective and undesirable motor or cognitive effects (e.g., sedation, paralysis, cognitive dysfunction) that impair a subject's ability to emit operant responses required for drug selfadministration. Because of this potential confound, the mere demonstration that a candidate medication decreases drug self-administration is not sufficient to recommend that medication as a treatment, and several strategies have been developed to address this confound. One of these strategies is to study medication effects on drug self-administration in the context of a choice between the target drug of abuse and a nondrug reinforcer such as food (Negus and Banks 2011; Banks and Negus 2017a; Banks et al. 2019). For example, Figure 1 shows choice between heroin and a food reinforcer in rhesus monkeys (Negus 2006) and rats (KL Schwienteck and ML Banks, unpubl.). For both species, daily experimental sessions consisted of five sequential compo- 


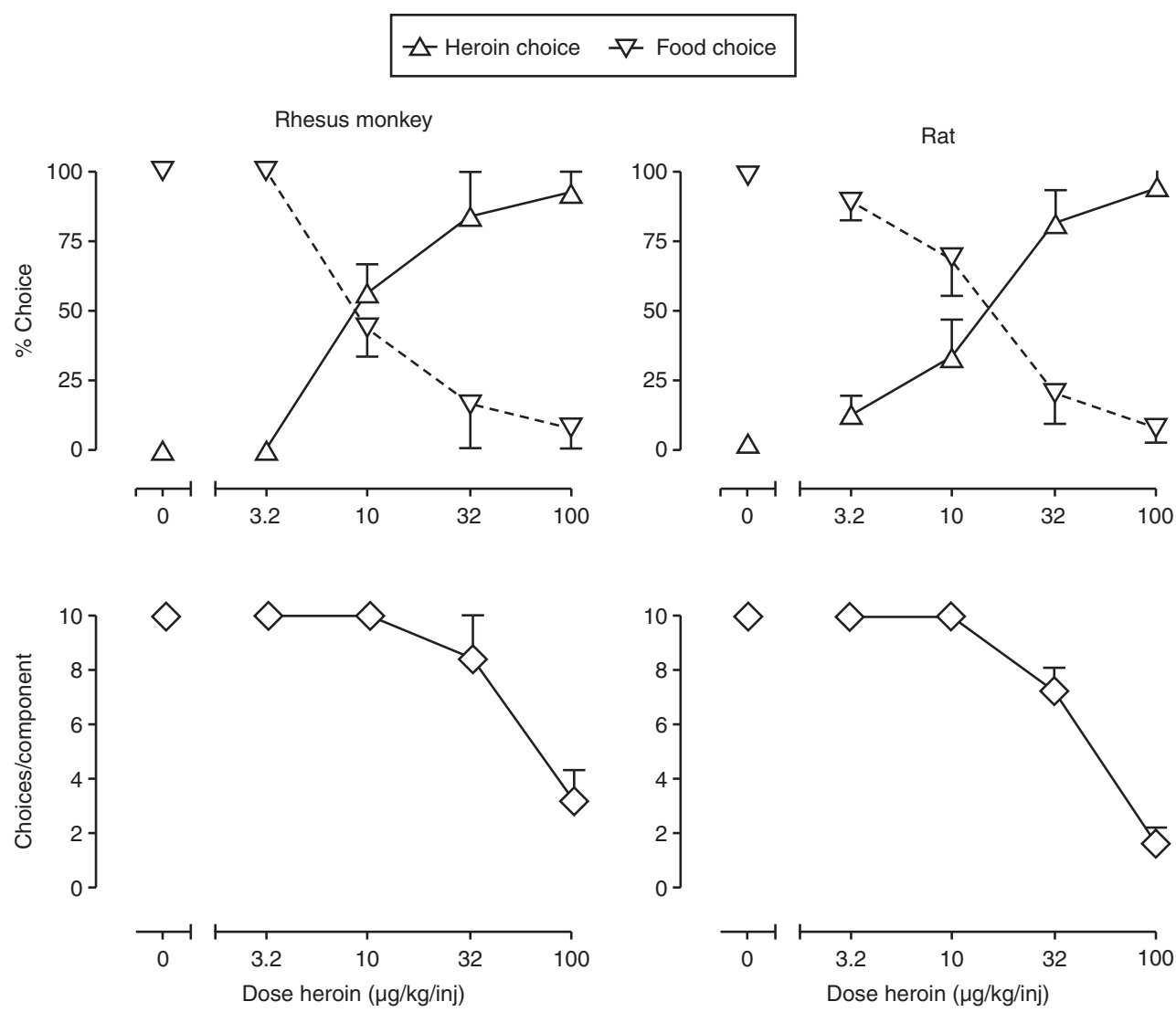

Figure 1. Dose-dependent choice between heroin and food in rhesus monkeys and rats. (Abscissa) Unit dose of heroin available during components of daily choice sessions. (Top ordinate) Percent of completed choices allocated to the heroin or food options. (Bottom ordinate) Total number of choices completed for both options. All points show mean \pm SEM for three monkeys and six rats. Heroin maintained a dose-dependent increase in heroin choice in both species. (MOR) $\mu$-Opioid receptor. (Figure adapted from data in Negus 2006 and unpublished observations from KL Schwienteck and ML Banks.)

nents, and during each component, subjects could respond either on a "heroin-associated" key to earn the available unit dose of heroin $(0-100 \mu \mathrm{g} / \mathrm{kg} / \mathrm{inj} \mathrm{IV})$ or on a separate "foodassociated" key to earn a food reinforcer (banana-flavored pellets in monkeys, brief access to liquid food in rats). Subjects could complete up to 10 total choices during each component. The top panels of Figure 1 show percent of choices completed on the heroin- or food-associated keys (monkeys) or levers (rats), and the bottom panels show the total number of choices completed. When " 0 " heroin (no injection) or the low dose of $3.2 \mu \mathrm{g} / \mathrm{kg} / \mathrm{inj}$ heroin was available, both monkeys and rats allocated their re- sponding exclusively toward food choices and earned all 10 available reinforcers. However, higher doses of $10-100 \mu \mathrm{g} / \mathrm{kg} / \mathrm{inj}$ heroin maintained a dose-dependent reallocation of behavior toward heroin choice. In both species, heroin choice was also associated with a dose-dependent decrease in the total number of choices completed, perhaps reflecting the sedative effects of high self-administered heroin doses. Overall, then, choice procedures yield dependent measures of both behavioral allocation (\% drug choice) and behavioral rate (total choices per component), and these two different dependent measures can be used to dissociate beneficial medication effects on drug reinforcement 
E.A. Townsend et al.

from nonselective and undesirable medication effects that might compromise a subject's ability to respond (Negus and Banks 2013; Banks et al. 2015; Banks and Negus 2017a). Specifically, as will be discussed below, changes in drug reinforcement manifest as changes in behavioral allocation, whereas undesirable effects that impair responding manifest as decreases in overall rate. An ideal medication in this procedure might be one that decreased heroin choice, increased food choice, and produced right shifts in the heroin choice dose-effect curve without reducing behavioral rate. Preclinical choice procedures have the additional advantages of both mimicking choice procedures used in human laboratory studies and modeling pathological choice of drug over other commodities in clinical drug abuse (Comer et al. 1998; Haney and Spealman 2008; Czoty et al. 2016; Lile et al. 2016).

A second critical factor that influences both the reinforcing effects of opioid agonists and the impact of candidate medications is the degree of opioid dependence and withdrawal. For example, Figure 2 shows heroin-vs.-food choice doseeffect functions in rhesus monkeys under conditions of nondependence, maintained opioid dependence, and opioid withdrawal (Negus
2006). In the "nondependent" condition, subjects had limited access to heroin during daily $2 \mathrm{~h}$ choice sessions. Daily heroin consumption was $\sim 600 \pm 200 \mu \mathrm{g} / \mathrm{kg} / \mathrm{d}$. This relatively small degree of opioid exposure was not sufficient to produce notable opioid dependence in that somatic opioid withdrawal signs were not apparent between choice sessions or if choice sessions were omitted. In the "maintained opioid dependence" condition, heroin intake during choice sessions was supplemented by additional heroin intake during the rest of each experimental day. Specifically, monkeys continued to choose between heroin and food during daily $2 \mathrm{~h}$ choice sessions, but they also had the opportunity to self-administer additional doses of $100 \mu \mathrm{g} / \mathrm{kg} /$ inj heroin every $15 \mathrm{~min}$ for the $21 \mathrm{~h}$ between daily choice sessions. In this context of augmented heroin access, daily heroin consumption increased approximately eightfold to $5000 \pm$ $300 \mu \mathrm{g} / \mathrm{kg} / \mathrm{d}$ heroin. So long as this augmented degree of heroin access and intake was sustained, there was little change in the heroin choice doseeffect function. However, when access to supplemental heroin was terminated, monkeys entered a state of spontaneous opioid withdrawal characterized both by the emergence of somatic

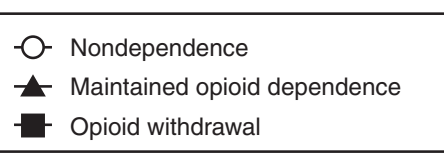

Rhesus monkey

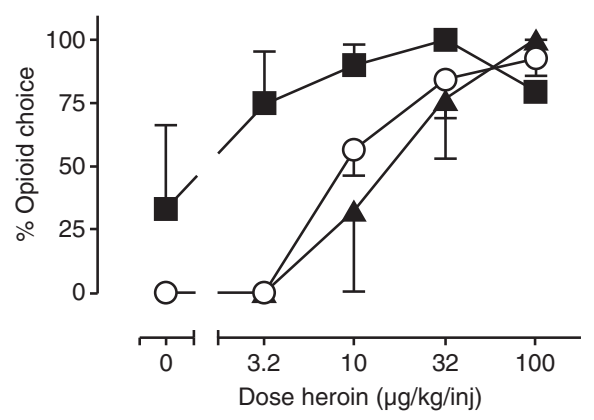

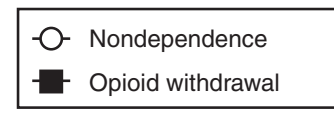

Rat

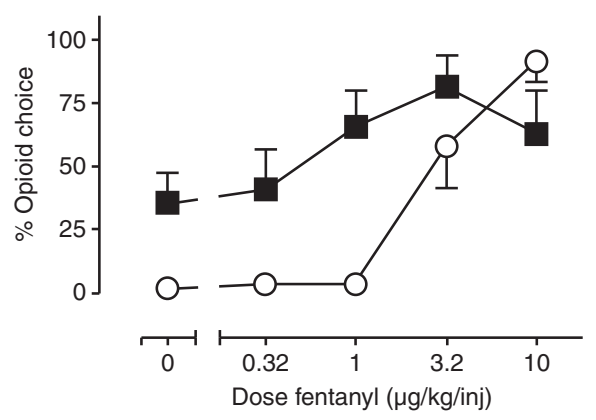

Figure 2. Effects of maintained opioid dependence and withdrawal on heroin-vs.-food choice in rhesus monkeys and fentanyl-vs.-food choice in rats. (Abscissa) Unit dose opioid. (Ordinate) Percent of completed choices allocated to heroin (monkeys) or fentanyl (rats). All points show mean \pm SEM for three monkeys or six rats. Sustained heroin dependence had little effect on heroin choice, but opioid withdrawal increased opioid choice. (Figure adapted from data in Negus 2006 and Townsend et al. 2019a.) 
withdrawal signs (data not shown) and by a dramatic increase in heroin choice manifested as a leftward/upward shift in the heroin choice doseeffect curve. Figure 2 also shows that similar withdrawal-associated increases in opioid-vs.food choice have been observed in rats choosing between fentanyl and food (Townsend et al. 2019a). Taken together, these increases in opioid choice provide evidence of a phenomenon that we have called "withdrawal-associated increase in opioid choice" (WIOC). The expression of WIOC in opioid-vs.-food choice procedures is consistent with evidence of withdrawal-associated increases in opioid self-administration under other schedules of reinforcement in both monkeys and rats (Spragg 1940; Thompson and Schuster 1964; Griffiths et al. 1975; Yanagita 1978; Lenoir et al. 2013). Moreover, WIOC can be conceptualized as a barrier to abstinence, because abstinence in an opioid-dependent subject necessarily involves exposure to a period of opioid withdrawal. During withdrawal, reinforcing effects of opioids are relatively high, reinforcing effects of competing nondrug alternative reinforcers are relatively low, and subjects are especially vulnerable to relapse. Last, as discussed below, medication effects on opioid reinforcement in a nondependent state can differ dramatically from their effects on WIOC in dependent subjects. This difference suggests that strategies for both treatment of opioid abuse with existing medications and for development of new medications should be tailored not only to opioids as the target drugs of abuse, but also to the level of opioid dependence (Banks et al. 2019).

\section{MEDICATION EFFECTS ON OPIOID CHOICE}

\section{Overview}

Figure 3 shows the cycle of pharmacological and behavioral effects that constitute OUD, and this figure also describes nodes within this cycle that can be targeted by medications. Briefly, an episode of opioid consumption is followed by drug distribution throughout the body both to peripheral sites and across the blood-brain barrier to central nervous system sites that include brain-reward areas like the ventral tegmental

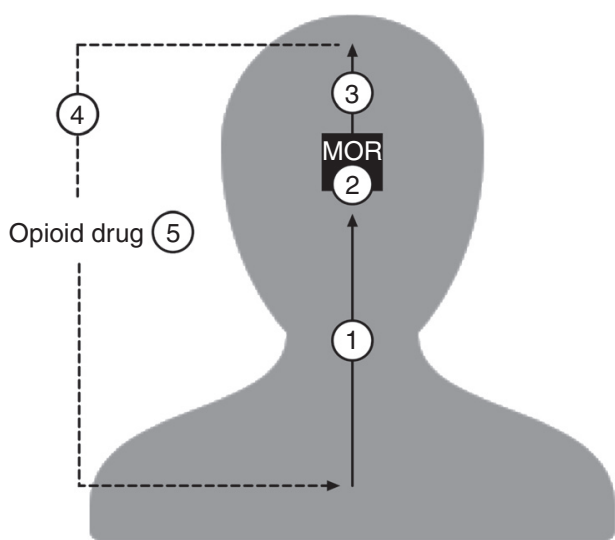

Figure 3. Schematic of steps in the opioid use disorder (OUD) cycle and nodes of potential intervention. OUD reflects a maladaptive cycle of pharmacological drug effects within a user's body and behavioral effects expressed by the user in the environment. Once a drug is consumed and absorbed into the body, it is distributed by (1) the circulatory system from the site of absorption to peripheral and central sites of action. In all of these sites, opioid drugs bind with (2) $\mu$-opioid receptors (MORs) to activate downstream effects (3). A subset of these effects may contribute to reinforcement and further drug-seeking and consumption (4). Other postreceptor effects may not contribute to reinforcement but may nonetheless be clinically problematic (e.g., respiratory depression, constipation). Medication approaches to OUD involve delivery of treatments "inside the skin" of the user to interrupt opioid distribution to brain (1, e.g., anti-opioid vaccines), opioid activation of MORs (2, e.g., the MOR antagonist naltrexone), or downstream consequences of opioid receptor activation (3, e.g., the $\alpha_{2}$-adrenergic receptor agonist clonidine). These medication approaches can be complemented by environmental manipulations "outside the skin" of the user such as contingency management or lawenforcement strategies intended to impede drug seeking and/or consumption (4, e.g., in-patient treatment or imprisonment) or to reduce opioid availability in the environment (5, e.g., drug interdiction efforts).

area (VTA) and nucleus accumbens (opioid distribution, Node 1). At each of these sites, opioid molecules bind and activate MORs (opioid receptor binding, Node 2). MOR activation then triggers intra- and intercellular downstream signaling that culminates in a range of physiological and behavioral opioid effects (postreceptor opioid effects, Nodes 3a, b, and c; see below). A 
E.A. Townsend et al.

subset of these effects will contribute to reinforcement of behaviors that result in acquisition and consumption of more opioid (Nodes 4 and 5) to propagate the cycle.

Three categories of "Node 3" opioid effects are especially relevant for treatment of OUD. First, MOR activation in brain-reward areas produces positive reinforcement that increases the probability of immediately preceding behaviors, including drug-seeking and drug-consummatory behaviors (Node 3a) (Negus and Dykstra 1989; Gardner 2011). These positive reinforcing effects are thought to be mediated in part by opioid-induced disinhibition of mesolimbic dopamine neurons and to be especially important for maintaining drug self-administration in nondependent subjects (Johnson and North 1992; Bergevin et al. 2002). Second, MOR activation at any of its targets may also recruit compensatory, intra- or intercellular opponent processes that defend homeostasis by opposing and limiting perturbations caused by the MOR agonist (Node 3b) (Gardner 2011; Koob 2019). These opponent processes have slower onsets and longer durations than MOR agonist effects, their net expression can accumulate with repeated opioid dosing, and they can manifest as opioid withdrawal signs when the opioid is absent. As one example of an intracellular opponent process, MOR activation acutely inhibits adenylyl cyclase activity to decrease cAMP levels in locus coeruleus noradrenergic neurons; however, repeated opioid exposure recruits a progressive increase in synthesis of the adenylyl cyclase protein as an opponent process that mitigates opioid effects. Subsequent opioid withdrawal then results in an overshoot in adenylyl cyclase activity and an increase in cAMP levels (Aghajanian 1978; Williams et al. 2001). Withdrawal signs mediated by opponent processes can be temporarily attenuated by reintroduction of the opioid, and, as a result, these opponent processes have the potential to function as negative reinforcers that promote further opioid consumption (i.e., opioid seeking and consumption may be reinforced because opioids provide temporary relief from the opponent process, the so-called "dark side of addiction") (Koob 2019). In preclinical studies of opioid choice, these negative reinforcement processes may be especially important in mediating WIOC (Negus and Banks 2018). Last, MOR activation may produce other effects (e.g., respiratory depression, constipation) that do not reinforce drug use but may nonetheless pose a risk to the user (Node 3c) (Boom et al. 2012; Akbarali et al. 2014).

Treatments that target these nodes have been examined in both animal and human laboratory models of opioid-vs.-food choice, and a summary of those results is shown in Table 1. The effects of treatments at each node will be reviewed below, along with a consideration of the degree to which effects in opioid-vs.-food choice procedures in laboratory animals translate to effects of these treatments on opioidvs.-food choice in human laboratory studies and/or in clinical experience with treatment of OUD patients.

\section{Medications Targeting Node 1: Opioid Distribution}

Blockade of opioid distribution to the central nervous system can be achieved through the use of opioid-targeted vaccines (i.e., immunopharmacotherapies). An opioid-targeted vaccine is comprised of a hapten that is structurally similar to a targeted opioid (e.g., heroin, fentanyl) that is conjugated to an immunogenic carrier protein and includes immunomodulatory adjuvants. Similar to the flu vaccine, opioid-vaccine administration stimulates an immune response and the subsequent production of "anti-opioid" antibodies. These antibodies circulate outside of the central nervous system and do not appear to interact with any known proteins or receptors. However, if a vaccinated subject ingests an opioid with a similar chemical structure to the hapten, the antibodies bind the opioid, and the resulting opioid-antibody complex is unable to pass through the bloodbrain barrier (see Bremer and Janda 2017; Banks et al. 2018). This intervention strategy would allow opioid entry into the body but would prevent the opioid from reaching and interacting with central MORs that mediate the abuse-related effects (Node 1 in Fig. 3). 
Medications for Opioid Use Disorder

Table 1. Summary of published manuscripts reporting on IV opioid self-administration under concurrent-choice schedules

\begin{tabular}{|c|c|c|c|c|c|}
\hline Drug & $\begin{array}{l}\text { Alternative } \\
\text { reinforcer }\end{array}$ & Species & Dependence & $\begin{array}{c}\text { Main effect on opioid } \\
\text { choice }\end{array}$ & References \\
\hline Heroin & Food pellet & Rhesus & $\mathrm{N}$ & $\begin{array}{l}\text { Methadone: } \varnothing \\
\text { Buprenorphine: } \downarrow \\
\text { Naloxone: } \downarrow\end{array}$ & Negus 2006 \\
\hline Remifentanil & Food pellet & Rhesus & $\mathrm{N}$ & $\begin{array}{l}\text { Naltrexone: } \downarrow \\
\text { Methocinnamox: } \downarrow\end{array}$ & Maguire et al. 2019 \\
\hline Heroin & Food pellet & Rhesus & $\mathrm{N}$ & Lorcaserin: $\uparrow$ & Townsend et al. 2019c \\
\hline Heroin & Brain stimulation & Rat & $\mathrm{N}$ & Naloxone: $\downarrow$ both & Gerber et al. 1985 \\
\hline Oxycodone & Food pellet & Rat & $\mathrm{N}$ & $\begin{array}{l}\text { Naltrexone: } \downarrow \\
\text { Oxycodone: } \varnothing\end{array}$ & Secci et al. 2016 \\
\hline Remifentanil & Food pellet & Rat & $\mathrm{N}$ & $\begin{array}{l}\text { Lorcaserin: } \emptyset \\
\text { Naltrexone: } \downarrow\end{array}$ & Panlilio et al. 2017 \\
\hline Fentanyl & Liquid food & Rat & $\mathrm{N}$ & $\begin{array}{l}\text { Naltrexone: } \downarrow \\
\text { Clonidine: } \uparrow \\
\text { Vaccine: } \downarrow\end{array}$ & Townsend et al. 2019a \\
\hline Heroin & Saccharin & Rat & $\mathrm{N}$ & $\begin{array}{r}\text { Postsession drug } \\
\text { availability: } \varnothing\end{array}$ & Gunawan et al. 2019 \\
\hline Heroin & Food pellet & Baboon & $\mathrm{Y}$ & $\begin{array}{l}\text { Methadone: } \downarrow \\
\text { Naloxone: } \uparrow\end{array}$ & Griffiths et al. 1975 \\
\hline Heroin & $\begin{array}{l}\text { Food pellet } \pm \\
\text { heroin }\end{array}$ & Baboon & $\mathrm{Y}$ & Morphine: $\downarrow$ & Wurster et al. 1977 \\
\hline Heroin & Food pellet & Baboon & $\mathrm{Y}$ & $\begin{array}{l}\text { Morphine: } \downarrow \\
\text { Naloxone: } \uparrow \\
\text { Secobarbital: } \varnothing\end{array}$ & Griffiths et al. 1981 \\
\hline Heroin & Food pellet & Rhesus & $\mathrm{Y}$ & $\begin{array}{l}\text { Methadone: } \downarrow \\
\text { Buprenorphine: } \uparrow\end{array}$ & Negus 2006 \\
\hline Heroin & Food pellet & Rhesus & $\mathrm{Y}$ & $\begin{array}{l}\text { Morphine: } \downarrow \\
\text { Amphetamine: } \varnothing \\
\text { Clonidine: } \varnothing \\
\text { Antalarmin: } \varnothing \\
5^{\prime} \text {-guanidinonaltrindole: } \varnothing\end{array}$ & Negus and Rice 2009 \\
\hline Heroin & Food Pellet & Rhesus & $\mathrm{Y}$ & Naltrexone: $\uparrow$ & Negus 2009 \\
\hline Remifentanil & Cocaine & Rhesus & $\mathrm{Y}$ & Morphine: $\varnothing$ & $\begin{array}{l}\text { Wade-Galuska et al. } \\
2011\end{array}$ \\
\hline Heroin & Money & Human & $\mathrm{PD}$ & Buprenorphine: $\downarrow$ & Mello et al. 1982 \\
\hline Heroin & Money & Human & $\mathrm{PD}$ & Buprenorphine: $\downarrow$ & Comer et al. 2001 \\
\hline Heroin & Money & Human & PD & $\begin{array}{c}\text { Buprenorphine/ } \\
\text { naloxone: } \downarrow\end{array}$ & Comer et al. 2005 \\
\hline Heroin & Money & Human & $\mathrm{PD}$ & Depot naltrexone: $\downarrow$ & Sullivan et al. 2006 \\
\hline Hydromorphone & Money & Human & $\mathrm{PD}$ & Buprenorphine: $\downarrow$ & Greenwald et al. 2002 \\
\hline Hydromorphone & Money & Human & $\mathrm{PD}$ & $\begin{array}{r}\text { Presession drug } \\
\text { availability: } \downarrow\end{array}$ & $\begin{array}{l}\text { Greenwald and Hursh } \\
2006\end{array}$ \\
\hline Hydromorphone & Money & Human & $\mathrm{PD}$ & $\begin{array}{r}\text { Postsession drug } \\
\text { availability: } \varnothing\end{array}$ & $\begin{array}{l}\text { Greenwald and } \\
\text { Steinmiller } 2009\end{array}$ \\
\hline Oxycodone & Money & Human & $\mathrm{PD}$ & Ibudilast: $\downarrow / \varnothing$ & Metz et al. 2017 \\
\hline
\end{tabular}

Columns show (1) the primary opioid option(s); (2) the alternative reinforcer(s) (sometimes also a drug); (3) the species in which studies were conducted; (4) whether the subjects were nonopioid-dependent $(\mathrm{N})$, opioid-dependent $(\mathrm{Y})$, or postdependent (PD); (5) the test medication and its main effect to decrease $(\downarrow)$, increase $(\uparrow)$, or have no effect $(\varnothing)$ on drug choice; and (6) the reference. 
E.A. Townsend et al.

Although the development of vaccines to treat opioid misuse can be traced back to the 1970s (Bonese et al. 1974), the effects of vaccination on opioid-vs.-food choice has only recently been examined (Townsend et al. 2019a). Rats trained to respond in a fentanyl-vs.-food choice procedure were administered a vaccine that consisted of a fentanyl hapten conjugated to the immunogenic protein tetanus toxoid and the adjuvants CpG ODN 1826 and alum. Following two vaccinations separated by 2 weeks, rats exhibited a near-maximal reallocation of behavior away from the fentanyl-associated lever and toward the food-associated lever by week 5 of the experiment (Fig. 4A). Importantly, fentanyl vaccine did not reduce operant responding and rather the number of reinforcers earned per component increased when large fentanyl doses were available because rats reallocated their behavior from low rates of fentanyl choice to higher rates of food choice. Furthermore, significant reductions in fentanyl-vs.-food choice were observed for at least 15 weeks. Finally, to determine whether the fentanyl vaccine effects were surmountable by larger fentanyl doses, rats were vaccinated again on week 17 and subsequently tested with a 10-fold larger fentanyl dose range on week 21 . Vaccine antagonism of fentanyl-vs.food choice was surmountable, allowing for the determination that the vaccine shifted the fentanyl choice $\mathrm{ED}_{50}$ value 21.8-fold relative to prevaccination conditions (Fig. 4B). Taken together, these results provide evidence that vaccination can produce robust and long-lasting reductions in opioid reinforcement, allowing nonopioid reinforcers to more effectively compete with the abused opioid.

These results in a fentanyl-vs.-food choice procedure in rats provide a rationale for the further development of fentanyl vaccines for the treatment or prevention of OUD (see Tunstall and Vendruscolo 2019 for commentary). However, previous work with a cocaine-targeted vaccine has shown that the demonstration of vaccine efficacy to decrease cocaine self-administration in rats (Kantak et al. 2000, 2001) does
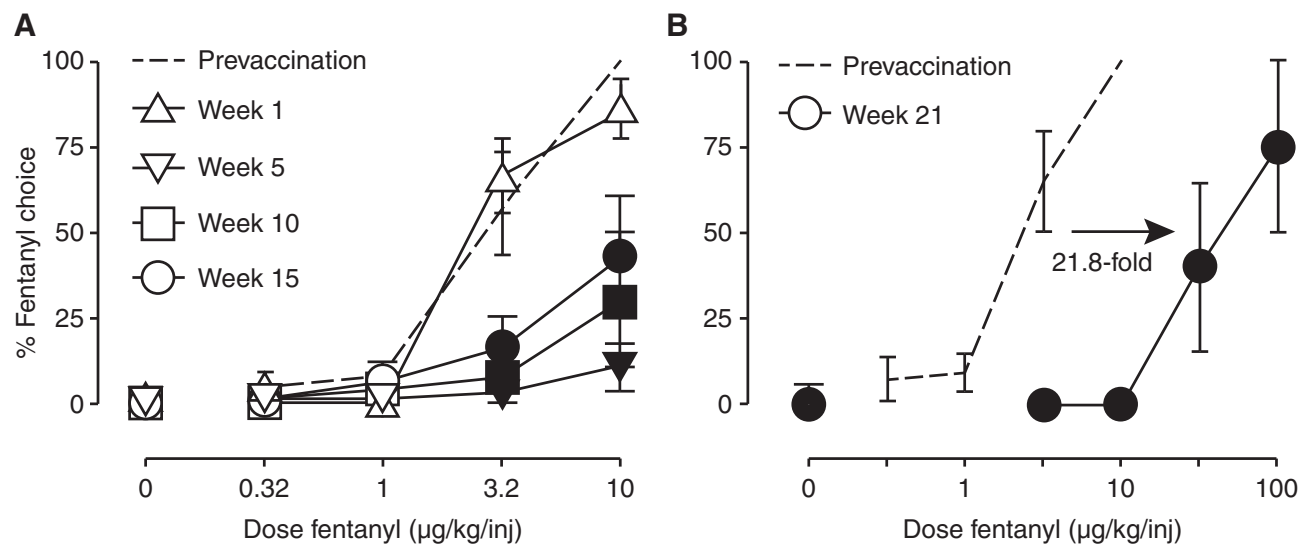

Figure 4. Effectiveness of a fentanyl vaccine to attenuate fentanyl-vs.-food choice in non-opioid-dependent male and female rats. (Abscissa) Intravenous unit dose of fentanyl in $\mu \mathrm{g} / \mathrm{kg}$. (Ordinate) Percentage of completed ratio requirements on the fentanyl-associated lever. $(A)$ Selected time points following conjugate fentanyl vaccine administration: prevaccination (week 0); week 1 and week 5: $n=3$ males, 3 females; week 10 and week 15: $n=2$ males, 2 females. (B) Surmountability of vaccine effects on fentanyl-vs.-food choice when the unit fentanyl dose was increased 10-fold. Dashed line represents prevaccination results (fentanyl dose range $0.32-10 \mu \mathrm{g} / \mathrm{kg} / \mathrm{inf}$ ) and the solid line represents week 21 of the vaccination schedule (fentanyl dose range $10-100 \mu \mathrm{g} / \mathrm{kg} / \mathrm{inf}$ ) in the four rats that maintained catheter patency ( $n=2$ males, 2 females). Points represent mean \pm SEM and filled symbols denote significant difference relative to baseline, defined as $P<0.05$ in $A$ and nonoverlapping $95 \%$ confidence limits of $\mathrm{ED}_{50}$ values in $B$. (Panels reprinted from Townsend et al. 2019a with permission from the authors.) 
Medications for Opioid Use Disorder

not necessarily predict the efficacy of the vaccine to attenuate cocaine use in humans (Kosten et al. 2014). Evidence suggests that the predictive validity of the preclinical development of drugtargeted vaccines could be increased through use of nonhuman primates as subjects (Evans et al. 2016; Bremer et al. 2017; Tenney et al. 2019). Hypothesized advantages of the use of nonhuman primates over rodents include immunological concordance, with greater similarity in B-cell and T-cell counts between rhesus monkeys and humans than rodents and humans (Vaccari and Franchini 2010; Caldwell et al. 2016). Given that these immune cells are directly involved in the production of antibodies (Bremer and Janda 2017), opioid-targeted vaccine effects in rhesus monkeys would be hypothesized to be more predictive of clinical effectiveness than effects observed in rodents. With this rationale in mind, ongoing studies are evaluating the effectiveness of a fentanyl-targeted vaccine to attenuate fentanyl-vs.-food choice and a heroin-targeted vaccine to attenuate heroin-vs.-food choice in male and female rhesus monkeys. These results will allow for comparison of vaccine effects on fentanyl-vs.food choice between rhesus monkeys and rats (i.e., Townsend et al. 2019a). In addition, these results will also allow for comparison of vaccine effects on opioid-vs.-food choice relative to other behavioral end points in rhesus monkeys, such as fentanyl or heroin potency to decrease schedule-controlled responding or produce thermal antinociception (Bremer et al. 2017; Tenney et al. 2019). This latter comparison of vaccine effects between procedures will inform whether the magnitude of vaccine effects differs between abuse-related (i.e., opioid-vs.-food choice) and non-abuse-related (schedule-controlled responding and thermal antinociception) end points. As this and other anti-opioid vaccines continue to be developed (e.g., Sulima et al. 2018; Baruffaldi et al. 2019; Schwienteck et al. 2019a), a critical component of the preclinical evaluation of these immunopharmacotherapies or other novel treatment strategies will be to compare their effectiveness relative to existing OUD pharmacotherapies, which will be discussed in upcoming sections of this review.

\section{Medications Targeting Node 2: MOR-Binding}

\section{MOR Antagonists}

The abuse-related effects of opioids are mediated most proximally by their actions on MOR, and most currently approved and clinically utilized OUD medications (i.e., naltrexone, buprenorphine, and methadone) interact directly with MORs. For example, the opioid antagonist naltrexone or the partial opioid agonist buprenorphine directly compete with the abused opioid in binding to the MOR. When a sufficient number $(>80 \%)$ of MOR are occupied by naltrexone or buprenorphine, the abused opioid is unable to activate enough MOR to produce an abuse-related effect (Greenwald et al. 2014). Previous preclinical studies using non-choice schedules of reinforcement have demonstrated that opioid self-administration can be attenuated by either selective MOR antagonists (Negus et al. 1993; Zernig et al. 1997) or genetic MOR deletion (Becker et al. 2000; Sora et al. 2001). For example, Figure 5 shows effects of the opioid antagonist naltrexone on heroin-vs.-food choice in nondependent rhesus monkeys and fentanyl-vs.-food choice in nondependent rats (Townsend et al. 2019a, 2019c). Specifically, continuous naltrexone infusion produced dose-dependent rightward shifts in the opioid choice dose-effect function (i.e., decreased opioid choice) in both species, and these doses of naltrexone did not reduce the total number of choices completed. Rather, as with the fentanyl vaccine described above, total reinforcers increased when high opioid doses were available, and subjects reallocated their behavior from low rates of opioid choice to higher rates of food choice. These findings agree with reports of chronic treatment of other MOR antagonists (e.g., naloxone or methocinnamox) administration decreasing opioid-vs.-food choice in nondependent monkeys (see Table 1 for details; Negus 2006; Maguire et al. 2019). More importantly, these findings are consistent with reports of reductions in heroin-vs.-money choice produced by opioid antagonists in nondependent (postdependent) humans (Sullivan et al. 2006) and with the efficacy of opioid antagonists as anti-relapse medications in highly motivated 
E.A. Townsend et al.

Rhesus monkey
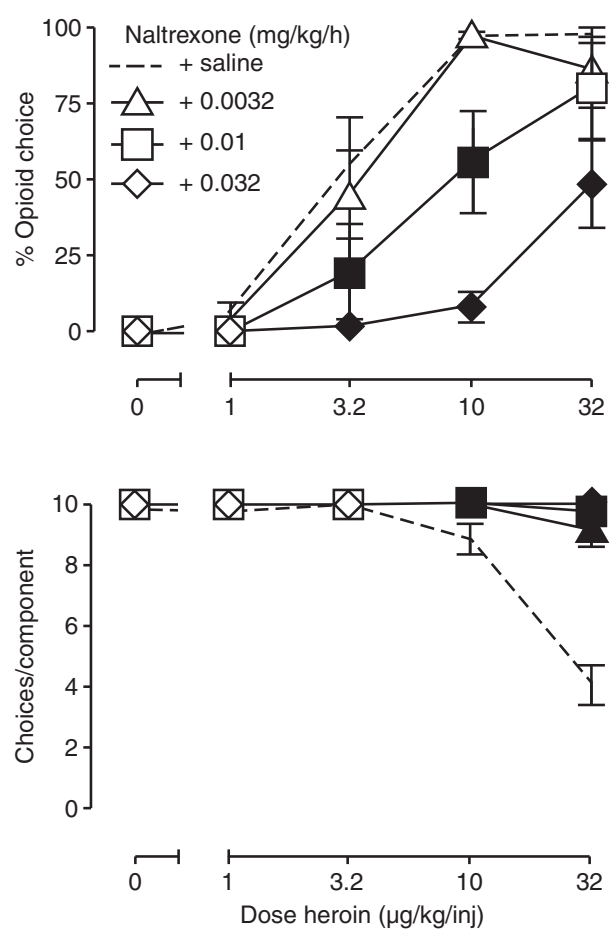

Rat
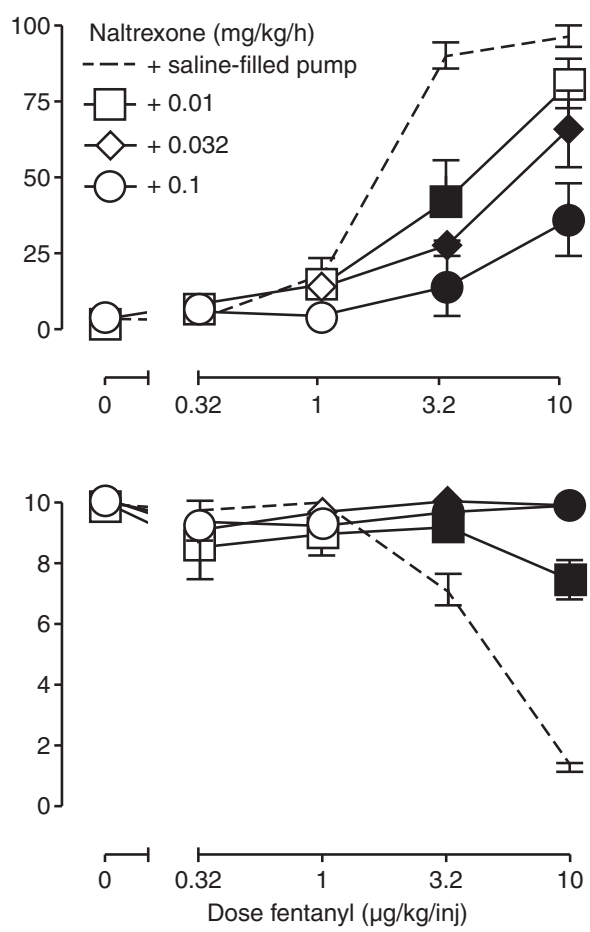

Figure 5. Chronic naltrexone effects on heroin choice in non-opioid-dependent rhesus monkeys and on fentanyl choice in non-opioid-dependent rats. (Abscissa) Unit dose opioid. (Ordinate) Percent of completed choices allocated to heroin (monkeys) or fentanyl (rats). All points show mean \pm SEM for six monkeys or six rats. (Panels reprinted from Townsend et al. 2019a and 2019c with permission from the authors.)

postdependent opioid abusers able to maintain compliance with antagonist treatment regimens (Jarvis et al. 2018, 2019; Nunes et al. 2019). In contrast to these results from nondependent/ postdependent subjects, Figure 6 shows that naltrexone administration to heroin-dependent rhesus monkeys produced dose-dependent leftward shifts in the heroin choice dose-effect curve (i.e., increased heroin choice). This increase in heroin choice was accompanied by precipitated signs of opioid withdrawal and resembles the withdrawal-associated increase in heroin choice produced by spontaneous heroin withdrawal shown in Figure 2. Effects of opioid antagonists on WIOC have not been examined, but the expected effects would be either no effect or an exacerbation of these increases in opioid choice. The effectiveness of opioid antagonists to precipitate somatic withdrawal signs and WIOC likely contributes to poor compliance with antagonist treatments clinically (Murphy et al. 2019; Nunes et al. 2019).

\section{MOR Agonists}

Buprenorphine. Buprenorphine also produces effects on opioid choice in nondependent animals that are similar to those of antagonists. For example, in nondependent monkeys or postdependent humans, buprenorphine maintenance produces a dose-dependent and antagonist-like decrease in opioid choice (see Table 1 for details; Mello et al. 1982; Comer et al. 2001, 2005; Greenwald et al. 2002; Negus 2006). Furthermore, high MOR occupancy by buprenorphine $(>80 \%)$ was necessary to attenuate the reinforcing effects of abused opioids in humans (Greenwald et al. 2014). However, unlike antagonists, termination of 5-d buprenorphine treatment in originally nondependent monkeys 

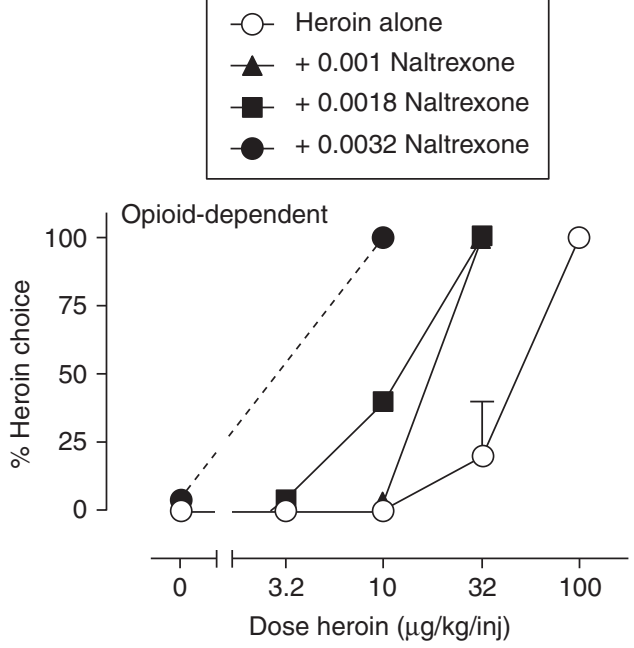

Figure 6. Naltrexone effects on heroin choice in one heroin-dependent rhesus monkey. (Abscissa) Unit dose heroin. (Ordinate) Percent of completed choices allocated to heroin. Naltrexone produced opposite effects on heroin choice depending on the state of heroin dependence. (Figure adapted from data in $\mathrm{Ne}$ gus 2009 with permission from the author.)

produced both the emergence of mild somatic withdrawal signs and WIOC (Negus 2006). These findings suggest that buprenorphine treatment regimens sufficient to reduce choice of a relatively high-efficacy opioid like heroin may also produce or sustain a relatively mild form of opioid dependence. This finding is consistent with other evidence to suggest that buprenorphine can function as a weak agonist capable of producing opioid dependence, and this dependence liability poses a risk in the use of buprenorphine as a maintenance medication in nondependent (i.e., postdependent) opioid abusers (Negus and Woods 1995).

Methadone. Like MOR antagonists and buprenorphine, high-efficacy MOR agonists such as morphine and methadone also bind to MORs and have efficacy as maintenance medications for treatment of OUD (Kreek et al. 2010; Mattick et al. 2014; Klimas et al. 2019; Noble and Marie 2019). However, these high-efficacy agonist medications differ from MOR antagonists and buprenorphine in both the degree of their MOR binding at clinically effective doses and the
Medications for Opioid Use Disorder

impact of opioid dependence on their safety and effectiveness.

With regard to MOR binding, agonist medications produce their effects at relatively low levels of receptor occupancy. This is especially true for methadone, which has very high efficacy relative to other opioid agonists (Selley et al. 1998), and which has been reported to occupy $\leq 30 \%$ of MORs at active doses in positron emission tomography studies in humans and rats (Melichar et al. 2005; King et al. 2009; Quelch et al. 2014). For comparison, clinically effective buprenorphine doses occupy $\geq 80 \%$ of MORs (Greenwald et al. 2003), and clinically effective naltrexone doses nearly saturate MORs (Lee et al. 1988; Weerts et al. 2008). The low levels of receptor occupancy produced by methadone suggest that it does not reduce effects of abused opioids by blocking access of those opioids to MORs. Indeed, methadone maintenance appears to leave most MORs unoccupied and available for binding to exogenous opioids, including abused opioids self-administered by a patient with OUD. Rather, the effectiveness of methadone maintenance despite low MOR occupancy suggests that methadone produces postreceptor effects that reduce the positive reinforcing effects of abused opioids or the negative reinforcing effects of opponent processes recruited by a history of opioid use. Studies that have examined agonist-medication effects on opioid-vs.-food choice in nondependent and opioid-dependent laboratory animals suggest that the latter is more important.

Clinically, high-efficacy agonist medications like methadone are used almost exclusively in patients with a high degree of opioid dependence (SAMHSA 2018). In agreement with this contextual use of agonist medications in dependent patients but not in nondependent patients, agonist medications have little effect on opioid choice in nondependent laboratory animals. An example of this phenomenon is shown above in Figure 2, wherein self-administration of supplemental heroin between heroin choice sessions had little effect on heroin choice during choice sessions in rhesus monkeys. Similarly, methadone maintenance in initially nondependent rhesus monkeys failed to reduce 
E.A. Townsend et al.

heroin-vs.-food choice up to methadone doses that produced an undesirable decrease in overall responding (Negus 2006). However, as shown in Figure 2 or described above with buprenorphine, repeated exposure to sufficiently high opioid-agonist doses will establish opioid dependence in originally nondependent subjects, and once this dependence is established, then termination of opioid exposure elicits somatic withdrawal signs and may also elicit WIOC. As with buprenorphine, the potential for agonist medications to produce opioid dependence poses a risk to their use in treatment of nondependent (including postdependent) opioid abusers.

However, once opioid dependence is established (e.g., by a history of opioid abuse), then opioid agonists can block WIOC and promote behaviors maintained by nonopioid alternative reinforcers (see Table 1 for details; Griffiths et al. 1975, 1981; Wurster et al. 1977; Negus 2006; Negus and Rice 2009). For example, Figure 7 shows effects of morphine on heroin-vs.-food choice in heroin-dependent rhesus monkeys. Experiments shown in this graph were conducted using the same choice procedure as described above to examine heroin choice dose-effect curves, but for the sake of simplifying data presentation, this graph shows the total percent of heroin choice across all heroin doses (Negus and Rice 2009). Under baseline conditions, monkeys had daily access to heroin during both $2-\mathrm{h}$ choice sessions and 21-h supplemental sessions between choice sessions, and during choice sessions, the subjects allocated $\sim 30 \%$ of their total choices to heroin and the remainder of their choices to food. Spontaneous withdrawal was introduced by terminating access to supplemental heroin for $1 \mathrm{~d}$, and withdrawal elicited the emergence of both somatic withdrawal signs and WIOC. Morphine administered during the period of heroin withdrawal produced a dose-dependent blockade of both somatic withdrawal signs and WIOC. Methadone produces similar effects (Negus 2006). We have argued that the effectiveness of high-efficacy opioid agonists to block WIOC contributes to their effectiveness as maintenance medications to decrease illicit opioid use. Overall, studies of opioidvs.-food choice have shown that opioid agonists like methadone are more effective to reduce WIOC in dependent subjects than to reduce opioid choice in nondependent subjects.

Summary and Implications for Medications Development. Figure 8 summarizes key points from research on the effectiveness of opioid medications to modulate opioid choice. Opioid use can be conceptualized as occurring in subjects who can migrate up or down a continuum from nondependent to highly opioid-dependent and vulnerable to withdrawal. As subjects range up and down this continuum of opioid depen-

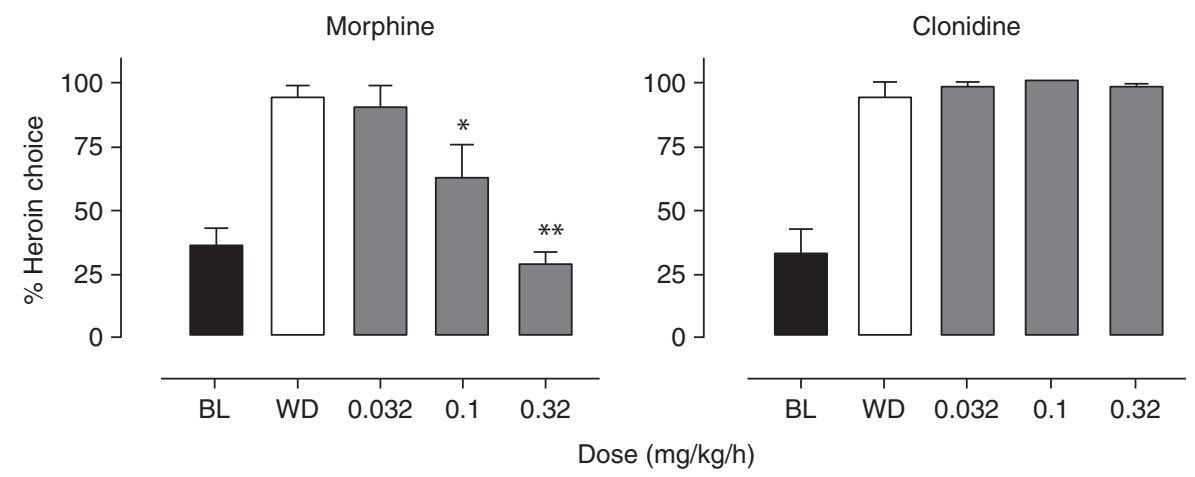

Figure 7. Effects of morphine and clonidine on withdrawal-associated increases in heroin choice. (Abscissa) Dose morphine or clonidine in $\mathrm{mg} / \mathrm{kg} / \mathrm{h}$. (Ordinate) Percent of choices allocated to heroin across all heroin doses. Morphine dose-dependently blocked withdrawal-associated increases in heroin choice, whereas clonidine did not up to doses that produced overt sedation. (BL) Baseline, (WD) withdrawal. (Figure reprinted with modifications from Negus and Rice 2009 with permission from the authors.) 


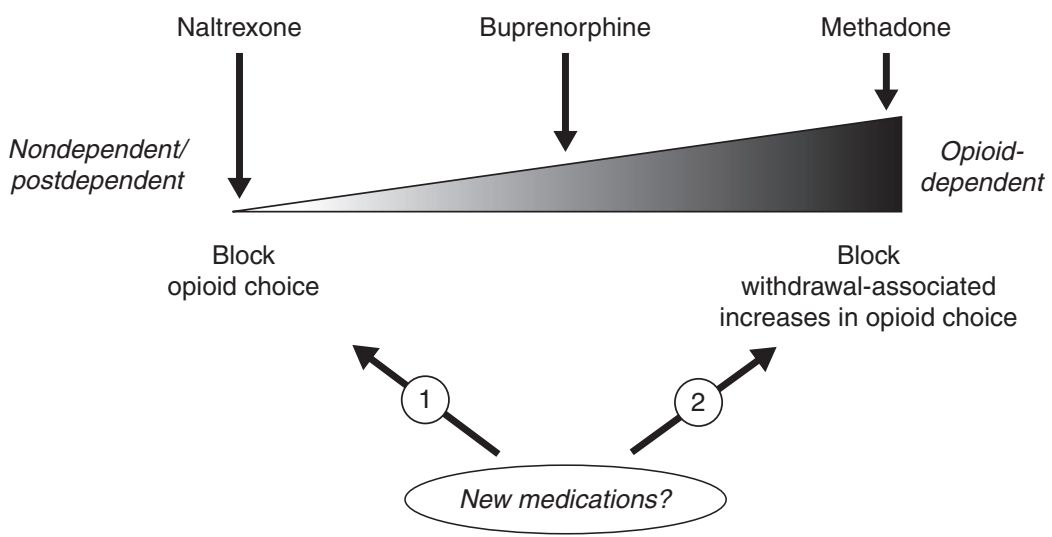

Figure 8. Schematic showing the clinical effectiveness of opioid medications under different states of opioid dependence. New medications could be evaluated for their ability to (1) block opioid choice in nondependent subjects, or (2) block withdrawal-associated increases in opioid choice in dependent subjects.

dence, therapeutic effectiveness to reduce opioid use is best achieved with a matching continuum of medications that progress from the opioid antagonist naltrexone in nondependent/postdependent subjects to the intermediate-efficacy agonist buprenorphine in modestly dependent subjects to the high-efficacy agonist methadone in highly dependent subjects. Similarly, the impact of these medications on opioidvs.-food choice in laboratory animals also varies along this continuum. Opioid antagonists like naltrexone block opioid choice in nondependent/postdependent subjects but increase opioid choice by producing WIOC in dependent subjects. Conversely, high-efficacy opioid agonists like morphine and methadone block WIOC in dependent subjects, but in nondependent subjects, they produce little change in opioid choice up to behaviorally toxic doses.

This array of medications provides a flexible and relatively effective set of pharmacological tools for use in the management of OUD in humans, and effects of these medications in nondependent vs. dependent humans parallels their effects on opioid choice in nondependent vs. dependent laboratory animals. However, as noted above, use of these opioid medications is complicated by factors that include low compliance with antagonists and abuse liability of agonists. Medications development seeks new strategies either (1) to improve opioid medica- tions, or (2) to develop nonopioid medications that are safer and/or more efficacious than opioid medications. Regarding the first of these strategies, the chief challenge with opioid antagonists has been compliance with medication regimens, and strategies to improve compliance include development of long-acting formulations (e.g., long-acting formulations of naltrexone) that minimize the required frequency of treatment and incentives for continuing naltrexone maintenance (Comer et al. 2007; Jarvis et al. 2019). Conversely, with opioid agonist medications, strategies to reduce abuse liability include development of agonist/antagonist formulations designed to retard abuse by parenteral routes of administration while retaining efficacy obtained via intended enteral routes of administration (e.g., suboxone, a mixture of buprenorphine and the opioid antagonist naloxone) (Comer et al. 2005; Sevarino and Kosten 2007). Other potential strategies to improve on existing opioid medications will be considered in "Future Directions," but these efforts have yet to be evaluated in laboratory-animal studies of opioid choice. Regarding the second strategy, opioid-choice procedures have also been used to evaluate the effect of candidate nonopioid medications intended to target postreceptor "Node 3" mechanisms of positive and negative reinforcement that may contribute to OUD. These will be considered next. 
E.A. Townsend et al.

Medications Targeting Node 3a: Postreceptor Effects and Positive Reinforcement

The mesolimbic dopamine pathway involves projections from the VTA to the nucleus accumbens, and activation of this pathway by drugs of abuse is hypothesized to contribute to drug-taking behavior. For example, activation of MORs located on VTA GABAergic interneurons disinhibits dopamine neurons, resulting in increased dopamine release in the nucleus accumbens and increased activation of postsynaptic dopamine receptors (Di Chiara and Imperato 1988; Johnson and North 1992; Corre et al. 2018). One conclusion from this body of literature is that opposing or blocking opioid-induced activation of mesolimbic dopamine signaling could attenuate opioid-induced positive reinforcement and thus may serve as an effective strategy for OUD treatment.

One strategy to reduce the positive reinforcing effects of abused opioids is to target nonopioid receptors to reduce opioid-activated mesolimbic dopamine signaling. For example, $\mathrm{G}_{\mathrm{q}} / \mathrm{G}_{11}$-protein-coupled $5-\mathrm{HT}_{2 \mathrm{C}}$ receptors are also located on VTA GABA-ergic neurons, and acute pretreatment with the $5-\mathrm{HT}_{2 \mathrm{C}}$ agonist MK-212 blunts morphine-induced increase in nucleus accumbens dopamine levels (Willins and Meltzer 1998). However, chronic treatment with the clinically available $5-\mathrm{HT}_{2 \mathrm{C}}$ agonist lorcaserin (Belviq) failed to attenuate heroin-vs.food choice in rhesus monkeys (Townsend et al. 2019c). Furthermore, these preclinical results were consistent with lorcaserin effects on oxycodone vs. money choice in humans (Brandt, Jones, Martinez, Manubay, Mogali, Ramey, Levin, and Comer, pers. comm.). Lorcaserin is also under consideration as a treatment for cocaine use disorder, but it failed to decrease cocaine choice in both rhesus monkeys and humans (Banks and Negus 2017b; Pirtle et al. 2019). Overall, these results from preclinical and human-laboratory choice studies do not support the continued development and evaluation of $5-\mathrm{HT}_{2 \mathrm{C}}$ agonists as candidate OUD medications.

Other pharmacological strategies to attenuate the positive reinforcing effects of opioids might be to block postsynaptic dopamine receptors. To the best of our knowledge, the effectiveness of dopamine receptor antagonists (e.g., risperidone or haloperidol) in preclinical opioidvs.-nondrug choice procedures, human laboratory opioid-vs.-money choice procedures, or double-blind placebo controlled clinical trials has not been determined. However, chronic treatment with dopamine receptor antagonists did not reduce cocaine- or methamphetaminevs.-food choice in either rhesus monkeys or rats (Negus 2003; Banks and Blough 2015; John et al. 2015; Thomsen et al. 2017), and dopamine receptor antagonists have also failed in clinical trials (Grabowski et al. 2000; Wachtel et al. 2002; Winhusen et al. 2014). Although attractive from a regulatory perspective, the broader scientific literature does not support the clinical utility of nonopioid medication approaches that oppose opioid-induced activation of the mesolimbic dopamine system.

\section{Medications Targeting Node 3b: Postreceptor Effects and Negative Reinforcement}

While acute opioid administration activates mesolimbic dopamine signaling in nondependent subjects, opioid withdrawal in dependent subjects can produce a decrease in mesolimbic dopamine release that may play an especially important role in modulating drug self-administration and the allocation of choice between drug and nondrug reinforcers (Shaham et al. 1996; He et al. 2004). If withdrawal-induced reductions in mesolimbic dopamine levels contribute to WIOC or other withdrawal signs, then direct or indirect dopamine agonists might be expected to alleviate WIOC or other withdrawal signs. In accordance with this hypothesis, the indirect dopamine agonists amphetamine and cocaine blocked the discriminative stimulus effects of opioid withdrawal in opioid-dependent rhesus monkeys (Sell and France 2002); however, amphetamine failed to reliably decrease WIOC in heroin-dependent monkeys (Negus and Rice 2009).

In addition to activating mesolimbic dopamine activity to produce positive reinforcing effects, abused opioids also engage other down- 
stream systems of intra- and intercellular signaling that can theoretically function as opponent processes and negative reinforcers of opioid selfadministration. Medications that target these downstream opponent processes may also produce therapeutically useful effects together with profiles of side-effects that are different from, and perhaps safer than, those of MOR medications. Research to investigate effects of these nonopioid medications on opioid choice (in nondependent/postdependent subjects) or on WIOC (in dependent subjects) is just beginning, and Table 1 summarizes the largely disappointing results of studies (Negus and Rice 2009; Townsend et al. 2019a) conducted so far. The most clinically relevant drugs are clonidine and lofexidine, $\alpha_{2}$-adrenergic receptor agonists approved for use in managing sympathomimetic signs of opioid withdrawal (Gold et al. 1979; Jasinski et al. 1985). However, despite the efficacy of clonidine to reduce some withdrawal signs, Figure 7 shows that clonidine failed to block WIOC in heroin-dependent rhesus monkeys (Negus and Rice 2009), and this agrees with the poor efficacy of clonidine as a monotherapy to prevent relapse in opioid abusers (Ling et al. 2005).

Noradrenergic systems constitute only one of several neurochemical "opponent process" systems that are engaged by repeated opioid exposure and become hyperactive during opioid withdrawal. Systems that use corticotropin-releasing factor (CRF) and the endogenous $\kappa$-opioid receptor (KOR) agonist dynorphin also are up-regulated during opioid use and withdrawal (Wee and Koob 2010; Logrip et al. 2011). This has led to the hypothesis that CRF and/or dynorphin might mediate WIOC or some other signs of withdrawal, and that antagonists of CRF receptors or KORs might attenuate these withdrawal signs. However, the CRF-1 receptor antagonist antalarmin did not reliably block WIOC in heroin-dependent monkeys, and the KOR antagonist 5'-guanidinonaltrindole exacerbated WIOC (Negus and Rice 2009). Consistent with these preclinical results, the CRF-1 receptor antagonist pexacerfont did not significantly reduce opioid-positive urines in patients with OUD (Morabbi et al. 2018).
However, subjective measures of craving, temptation, and opioid withdrawal scores were significantly reduced in the pexacerfont treatment group compared to placebo. KOR antagonists have not yet been tested in either human laboratory opioid choice studies or clinical trials.

Taken together, these data argue against an exclusive role for $\alpha_{2}$-adrenergic agonists, CRF-1 or KOR antagonists, or indirect dopamine agonists for the treatment of dependent opioid abusers, but much additional research is required to clarify the potential utility of these medications across a more diverse range of clinically relevant conditions. For example, these drugs have been examined at only one, relatively high level of opioid dependence for which buprenorphine was also not reliably effective in blocking withdrawal-associated increases in heroin choice (Negus and Rice 2009). Further research will be required to determine whether these or related medications might be more effective at lower levels of opioid dependence or in postdependent opioid users. Moreover, combinations of these medications may improve clinical effectiveness by targeting multiple systems dysregulated by opioid abuse.

\section{Medications Targeting Node 3c: Postreceptor Toxic Effects}

In addition to medications that directly target OUD-related behaviors, there is also a growing interest in the development and evaluation of medications to address clinically problematic effects of OUD or OUD medications. These priorities have been recently outlined by the NIDA Division of Therapeutics and Medical Consequences (Rasmussen et al. 2019). The most severe undesirable effect associated with opioid agonist exposure is respiratory depression. Among current maintenance therapies for OUD, methadone poses the greatest risk of fatal respiratory depression, particularly during the initiation of treatment (Degenhardt et al. 2009). Evidence suggests that respiratory stimulants such as AMPA antagonists can mitigate opioid-induced respiratory depression (e.g., Haw et al. 2016), providing evidence that 
E.A. Townsend et al.

respiratory stimulants could be coadministered with methadone or other high-efficacy MOR agonists to reduce the likelihood of fatal overdose.

In addition to the risk of respiratory depression and death, constipation is another common side effect of repeated or chronic exposure to MOR agonists (Camilleri et al. 2014; Webster 2015). Medication options for opioid-induced constipation include conventional laxatives and stool softeners, although these medications are not universally effective (Camilleri et al. 2014; Dorn et al. 2014). In addition, MOR antagonists that possess poor blood-brain barrier permeability (i.e., peripherally restricted MOR antagonists) are available for patients that do not respond to conventional laxatives and stool softeners. These medications (e.g., methylnaltrexone, naloxegol) are intended to counteract the constipation-inducing effects of MOR agonists at MORs located in the gastrointestinal tract without interacting with centrally located MORs, where antagonism would be expected to precipitate withdrawal in opioid-dependent patients (Pannemans et al. 2018; Uritsky 2019). Opioid-induced constipation has been reported to decrease compliance to treatment regimens of prescription opioids (Panchal et al. 2007), providing evidence that the alleviation of this side effect may increase compliance for OUD agonist treatments. However, the degree to which these medications targeting postreceptor toxic effects of opioids might improve patient compliance of medications that directly target OUD-related behaviors remains to be empirically determined.

\section{Environmental Manipulations Targeting Nodes 4 and 5: Opioid Cost and Availability}

This review focuses primarily on the use of opioid choice procedures to assess candidate medications, but OUD treatment and prevention also often involves environmental manipulations intended to increase opioid cost and/or reduced opioid availability, and choice procedures have also been used to evaluate effects of some environmental manipulations. For exam- ple, we and others have demonstrated that simply introducing alternative nondrug reinforcer availability concurrently to the abused opioid shifts the potency of the opioid to function as a reinforcer (Lenoir et al. 2013; Venniro et al. 2018; Townsend et al. 2019b). For example, a unit fentanyl dose of $1 \mu \mathrm{g} / \mathrm{kg} / \mathrm{inf}$ functioned as a reinforcer and maintained peak rates of behavior when only intravenous fentanyl was available during the drug self-administration session in both male and female rats (Townsend et al. 2019b). However, when both liquid food and intravenous fentanyl were concurrently available in these same rats, a unit dose of $3.2 \mu \mathrm{g} /$ $\mathrm{kg} /$ inf was necessary for fentanyl to function as a reinforcer as demonstrated by behavioral allocation over the alternative food reinforcer. Furthermore, the potency shift observed by Townsend et al. (2019b) is consistent with other preclinical studies examining other concurrently available nondrug reinforcers such as social interaction (Venniro et al. 2018, 2019). However, the availability of social contact alone during the heroin self-administration was insufficient to attenuate heroin intake (Lacy et al. 2016). These latter results suggest that the contingencies of alternative nondrug reinforcer availability are one important determinant for alternative nondrug reinforcer effectiveness to reduce drug self-administration. Thus, free availability of alternative nondrug reinforcers (e.g., food or social) is insufficient to modulate drug-taking behavior. Other environmental manipulations such as exercise (Smith et al. 2018) or enrichment (Hofford et al. 2017) offered outside the opioid self-administration session have been shown to reduce rates of opioid self-administration in rats. However, whether these environmental manipulations reduce opioid-vs.-nondrug choice in nonhumans or humans remains to be empirically determined.

Opioid choice could also be reduced by increasing the fixed-ratio (FR) requirement (i.e., cost) for the opioid or decreasing the FR requirement for the alternative nondrug reinforcer. Unpublished observations from our laboratory suggest that increasing the FR requirement for the opioid is more effective than decreasing the FR requirement for the alternative food reinforc- 
er in nonopioid-dependent rats (KL Schwienteck and ML Banks, unpubl.). These unpublished results are generally consistent with published results examining the effects of FR manipulations on cocaine-vs.-food choice in both rats (Cantin et al. 2010; Thomsen et al. 2013) and monkeys (Nader and Woolverton 1992; Negus 2003). Although increasing relative drug cost can influence drug-vs.-nondrug choice, the societal cost (e.g., strict enforcement of drug laws) for achieving and maintaining increases in drug price sufficient to reduce drug consumption can be difficult (Chisholm et al. 2006).

Efforts to address the opioid crisis also include attempts to reduce opioid availability in the environment. These efforts are intended to decrease the likelihood that opioid-seeking individuals encounter these drugs (Node 5 in Fig. 3). For example, U.S. law enforcement seeks to decrease the supply of illicit opioids (e.g., heroin, fentanyl) by intercepting and confiscating a proportion of these drugs at points of entry into the country (U.S. Drug Enforcement Administration 2018 National Threat Assessment). In addition, the availability of prescription opioids (e.g., methadone, buprenorphine) is limited through policies and guidelines that are intended to regulate the circumstances under which these medications can be prescribed (Dowell et al. 2016). These efforts to regulate opioid availability in the environment can also be examined in the laboratory by manipulating access conditions to the reinforcer (i.e., closed or open economy). For example, providing saccharin or intravenous heroin access following the heroinvs.-saccharin choice session did not significantly alter heroin-vs.-saccharin choice behavior in rats, suggesting minimal or no satiation of heroin or saccharin choice behavior (Gunawan et al. 2019). Overall, given the ongoing severity of the opioid crisis, current environmental strategies alone to reduce opioid availability or increase illicit opioid cost are insufficient.

The effects of a complete blockade of opioid distribution can be modeled with preclinical drug self-administration procedures. Under single-operant conditions, subjects can be trained to self-administer an opioid until stable behav- ior is observed. Next, the heroin solution can be replaced with saline. Given that saline does not activate brain reward pathways and function as a reinforcer, saline substitution decreases operant responding previously maintained by the opioid (i.e., extinction; de Wit and Stewart 1983). Under opioid-vs.-food choice conditions, substitution of saline for a previously self-administered opioid results in not only a decrease in operant responding maintained by the opioid, but also a corresponding increase in behavior emitted toward the nonopioid alternative reinforcer (Townsend et al. 2019c). Although these preclinical results demonstrate that efforts to reduce opioid availability result in decreased opioid-taking behavior and behavioral reallocation to an alternative nondrug reinforcer, the practical application of this approach outside of a controlled laboratory environment is much more difficult to achieve.

\section{FUTURE DIRECTIONS}

In addition to the mechanisms discussed above, novel opioid agonists and nonopioid receptor ligands are also emerging as potential candidate OUD medications, and two illustrative classes of candidate medications are discussed here. First, an emerging literature has revealed that structurally distinct ligands can activate the same Gprotein-coupled receptor in different ways to activate different profiles of second-messenger signaling coupled to that receptor (Kenakin 1995, 2015; Jarpe et al. 1998; Lane et al. 2017). For example, TRV130 (oliceridine) is a first-in-class G-protein-biased (GPB)-MOR agonist that has advanced to clinical trials. Relative to existing opioids like morphine, oliceridine retains high efficacy to activate G-protein signaling, but has low efficacy for the $\beta$-arrestin-2 signaling pathway (DeWire et al. 2013). In both preclinical and clinical studies, oliceridine produced antinociception/analgesia with reduced respiratory depression relative to conventional MOR agonists like morphine (DeWire et al. 2013; Soergel et al. 2014; Singla et al. 2017). Although evidence of some undesirable MOR agonist effects were reduced with oliceridine, abuse-related effects were still evident (Altarifi et al. 2017; Zamarripa 
E.A. Townsend et al.

et al. 2018; Schwienteck et al. 2019b). Thus, there is the potential for oliceridine or other emerging high-efficacy GPB-MOR agonists (Schmid et al. 2017) to function as safer alternatives to methadone as agonist-maintenance OUD medications in opioid-dependent patients. In addition to GPB-MOR agonists, other novel MOR agonists have emerged that have MOR agonist efficacy higher than naltrexone but lower than buprenorphine. For example, 17 -cyclopropylmethyl-3,14 $\beta$-dihydroxy- $4,5 \alpha$ epoxy- $6 \alpha$-(isoquinoline-3-carboxamido)morphinan (NAQ) is a low-efficacy MOR agonist that produces weak abuse-related effects, does not precipitate somatic opioid withdrawal signs like naltrexone, and antagonizes high-efficacy MOR agonist antinociception in rats and rhesus monkeys (Altarifi et al. 2015; Cornelissen et al. 2018; Schwienteck et al. 2019b). NAQ also reversed morphine withdrawal-associated depression of intracranial self-stimulation in rats (Altarifi et al. 2015), suggesting that NAQ may have the potential to mitigate WIOC in the context of opioid-vs.-food choice procedures.

A second emerging strategy is to utilize a nonopioid medication as an adjunct therapy to an opioid medication. For example, although clonidine was not effective as a monotherapy for OUD (Ling et al. 2005), the combination of clonidine and buprenorphine was superior to buprenorphine alone in attenuating stress-induced relapse of opioid use in humans (Kowalczyk et al. 2015). Other emerging nonopioid receptor targets for candidate adjuncts include the nociception opioid peptide (NOP) receptor, and mixed MOR and NOP agonist compounds have been synthesized (Linz et al. 2014; Ding et al. 2016, 2018). For example, cebranopadol is a high-efficacy mixed MOR and NOP agonist that has shown effectiveness in treating pain in several clinical trials (Scholz et al. 2018; Koch et al. 2019). In addition, cebranopadol also showed lower abuse-related subjective effects in humans compared to hydromorphone (Göhler et al. 2019). However, whether these mixed MOR and NOP agonists attenuate opioid choice in either laboratory animals or humans remains to be empirically determined.

\section{CONCLUDING REMARKS}

Opioid abuse remains a public health problem, and development of safe and effective medications remains a priority for substance use disorder research as outlined in the NIH Helping to End Addiction Long-Term (HEAL) initiative (www.nih.gov/research-training/medical-resear ch-initiatives/heal-initiative). Currently approved opioid medications exist on a continuum of pharmacological efficacy at the MOR and range from the opioid antagonist naltrexone to the intermediate-efficacy agonist buprenorphine and the high-efficacy agonist methadone. The effectiveness of these medications to reduce opioid choice is governed by the state of opioid dependence and withdrawal in the subject being treated. Antagonists reduce opioid choice in nondependent and postdependent subjects, whereas intermediate- and high-efficacy agonists block WIOC in opioid-dependent subjects. However, use of these medications is limited by factors that include poor compliance with antagonists and abuse liability of agonists. A range of nonopioid medications has been evaluated in accordance with hypotheses regarding neural systems that may be pathologically dysregulated by opioid abuse. $\alpha_{2}$-Adrenergic receptor agonists such as clonidine and lofexidine are the principal nonopioid medications used in OUD treatment to alleviate some somatic signs of opioid withdrawal, but these compounds are not effective as stand-alone maintenance medications to prevent WIOC in laboratory animals or opioid use in patients. CRF-1 receptor antagonists, KOR antagonists, and indirect dopamine agonists are other nonopioids that have been tested but that failed to reliably reduce opioid choice in dependent subjects. However, future research with these agents is warranted, and new agents that interact with the MOR in novel ways, such as GPB MOR agonists, or nonopioid adjuncts to combine with currently approved opioid treatments are emerging (Rasmussen et al. 2019). Procedures that permit assessment of opioid choice in nondependent subjects and of WIOC in opioid-dependent subjects provide a versatile experimental platform for efficient assessment 
and prioritization of emerging candidate medications (Banks et al. 2019).

\section{COMPETING INTEREST STATEMENT}

All authors declare there are no competing financial interests or potential conflicts of interest in relation to the research described.

\section{ACKNOWLEDGMENTS}

The authors are supported in part by National Institutes of Health Grants R01DA026946, UH3DA041146, UG3DA050311, P30DA0339 34, and F32DA047026. The National Institute on Drug Abuse had no role in study design, collection, analysis, or interpretation of the data, or in the writing or decision to submit the manuscript for publication. The manuscript content is solely the responsibility of the authors and does not necessarily reflect the official views of the National Institutes of Health.

\section{REFERENCES}

Aghajanian GK. 1978. Tolerance of locus coeruleus neurones to morphine and suppression of withdrawal response by clonidine. Nature 276: 186-188. doi:10.1038/ $276186 \mathrm{a} 0$

Ahmed SH. 2010. Validation crisis in animal models of drug addiction: beyond non-disordered drug use toward drug addiction. Neurosci Biobehav Rev 35: 172-184. doi:10 .1016/j.neubiorev.2010.04.005

Akbarali HI, Inkisar A, Dewey WL. 2014. Site and mechanism of morphine tolerance in the gastrointestinal tract. Neurogastroenterol Motil 26: 1361-1367. doi:10.1111/ nmo.12443

Altarifi AA, Yuan Y, Zhang Y, Selley DE, Negus SS. 2015. Effects of the novel, selective and low-efficacy $\mu$ opioid receptor ligand NAQ on intracranial self-stimulation in rats. Psychopharmacology (Berl) 232: 815-824. doi:10 .1007/s00213-014-3719-7

Altarifi AA, David B, Muchhala KH, Blough BE, Akbarali H, Negus SS. 2017. Effects of acute and repeated treatment with the biased $\mu$ opioid receptor agonist TRV130 (oliceridine) on measures of antinociception, gastrointestinal function, and abuse liability in rodents. J Psychopharmacol 31: 730-739. doi:10.1177/0269881116689257

American Psychiatric Association. 2013. Diagnostic and statistical manual of mental disorders, 5th ed. American Psychiatric Association, Arlington, VA.

Ator NA, Griffiths RR. 2003. Principles of drug abuse liability assessment in laboratory animals. Drug Alcohol Depend 70: S55-S72. doi:10.1016/S0376-8716(03)00099-1
Banks ML, Blough BE. 2015. Effects of environmental manipulations and treatment with bupropion and risperidone on choice between methamphetamine and food in rhesus monkeys. Neuropsychoharmacology 40: 21982206. doi:10.1038/npp.2015.63

Banks ML, Negus SS. 2012. Preclinical determinants of drug choice under concurrent schedules of drug self-administration. Adv Pharmacol Sci 2012: 281768.

Banks ML, Negus SS. 2017a. Insights from preclinical choice models on treating drug addiction. Trends Pharmacol Sci 38: 181-194. doi:10.1016/j.tips.2016.11.002

Banks ML, Negus SS. 2017b. Repeated 7-day treatment with the $5-\mathrm{HT}_{2 \mathrm{C}}$ agonist lorcaserin or the $5-\mathrm{HT}_{2 \mathrm{~A}}$ antagonist pimavanserin alone or in combination fails to reduce cocaine vs food choice in male rhesus monkeys. Neuropsychopharmacology 42: 1082-1092. doi:10.1038/npp.2016 .259

Banks ML, Hutsell BA, Schwienteck KL, Negus SS. 2015. Use of preclinical drug vs. food choice procedures to evaluate candidate medications for cocaine addiction. Curr Treat Options Psychiatry 2: 136-150. doi:10.1007/s40501-0150042-9

Banks ML, Olson ME, Janda KD. 2018. Immunopharmacotherapies for treating opioid use disorder. Trends Pharmacol Sci 39: 908-911. doi:10.1016/j.tips.2018.08.001

Banks ML, Townsend EA, Negus SS. 2019. Testing the 10 most wanted: a preclinical algorithm to screen candidate opioid use disorder medications. Neuropsychopharmacology 44: 1011-1012. doi:10.1038/s41386-019-0336-5

Baruffaldi F, Raleigh MD, King SJ, Roslawski MJ, Birnbaum AK, Hassler C, Carroll FI, Runyon SP, Winston S, Pentel PR, et al. 2019. Formulation and characterization of conjugate vaccines to reduce opioid use disorders suitable for pharmaceutical manufacturing and clinical evaluation. Mol Pharm 16: 2364-2375. doi:10.1021/acs .molpharmaceut.8b01296

Becker A, Grecksch G, Brödemann R, Kraus J, Peters B, Schroeder H, Thiemann W, Loh HH, Höllt V. 2000. Morphine self-administration in $\mu$-opioid receptor-deficient mice. Naunyn-Schmiedebergs Arch Pharmacol 361: $584-$ 589. doi:10.1007/s002100000244

Bergevin A, Girardot D, Bourque M-J, Trudeau L-E. 2002. Presynaptic $\mu$-opioid receptors regulate a late step of the secretory process in rat ventral tegmental area GABAergic neurons. Neuropharmacology 42: 1065-1078. doi:10 .1016/S0028-3908(02)00061-8

Bonese KF, Wainer BH, Fitch FW, Rothberg RM, Schuster CR. 1974. Changes in heroin self-administration by a rhesus monkey after morphine immunisation. Nature 252: 708-710. doi:10.1038/252708a0

Boom M, Niesters M, Sarton E, Aarts L, Smith TW, Dahan A. 2012. Non-analgesic effects of opioids: opioid-induced respiratory depression. Curr Pharm Des 18: 5994-6004. doi:10.2174/138161212803582469

Bremer PT, Janda KD. 2017. Conjugate vaccine immunotherapy for substance use disorder. Pharmacol Rev 69: 298-315. doi:10.1124/pr.117.013904

Bremer PT, Schlosburg JE, Banks ML, Steele FF, Zhou B, Poklis JL, Janda KD. 2017. Development of a clinically viable heroin vaccine. J Am Chem Soc 139: 8601-8611. doi:10.1021/jacs.7b03334 
E.A. Townsend et al.

Caine SB, Negus SS, Mello NK. 1999. Method for training operant responding and evaluating cocaine self-administration behavior in mutant mice. Psychopharmacology (Berl) 147: 22-24. doi:10.1007/s002130051134

Caldwell RG, Marshall P, Fishel J. 2016. Method validation and reference range values for a peripheral blood immunophenotyping assay in non-human primates. J Immunotoxicol 13: 64-76. doi:10.3109/1547691X.2014 .1001098

Camilleri M, Drossman DA, Becker G, Webster LR, Davies AN, Mawe GM. 2014. Emerging treatments in neurogastroenterology: a multidisciplinary working group consensus statement on opioid-induced constipation. Neurogastroenterol Motil 26: 1386-1395. doi:10.1111/ nmo.12417

Cantin L, Lenoir M, Augier E, Vanhille N, Dubreucq S, Serre F, Vouillac C, Ahmed SH. 2010. Cocaine is low on the value ladder of rats: possible evidence for resilience to addiction. PLoS ONE 5: e11592. doi:10.1371/journal .pone.0011592

Chisholm D, Doran C, Shibuya K, Rehm J. 2006. Comparative cost-effectiveness of policy instruments for reducing the global burden of alcohol, tobacco and illicit drug use. Drug Alcohol Rev 25: 553-565. doi:10.1080/ 09595230600944487

Ciccarone D. 2019. The triple wave epidemic: supply and demand drivers of the US opioid overdose crisis. Int $J$ Drug Policy 71: 183-188. doi:10.1016/j.drugpo.2019.01 .010

Comer SD, Collins ED, Wilson ST, Donovan MR, Foltin RW, Fischman MW. 1998. Effects of an alternative reinforcer on intravenous heroin self-administration by humans. Eur J Pharmacol 345: 13-26. doi:10.1016/S0014-2999 (97)01572-0

Comer SD, Collins ED, Fischman MW. 2001. Buprenorphine sublingual tablets: effects on IV heroin self-administration by humans. Psychopharmacology 154: 28-37.

Comer SD, Walker EA, Collins ED. 2005. Buprenorphine/ naloxone reduces the reinforcing and subjective effects of heroin in heroin-dependent volunteers. Psychopharmacology (Berl) 181: 664-675. doi:10.1007/s00213-0050023-6

Comer SD, Sullivan MA, Hulse GK. 2007. Sustained-release naltrexone: novel treatment for opioid dependence. Expert Opin Investig Drugs 16: 1285-1294. doi:10.1517/ 13543784.16.8.1285

Cornelissen JC, Obeng S, Rice KC, Zhang Y, Negus SS, Banks ML. 2018. Application of receptor theory to the design and use of fixed-proportion $\mu$-opioid agonist and antagonist mixtures in rhesus monkeys. J Pharmacol Exp Ther 365: 37-47. doi:10.1124/jpet.117.246439

Corre J, van Zessen R, Loureiro M, Patriarchi T, Tian L, Pascoli V, Lüscher C. 2018. Dopamine neurons projecting to medial shell of the nucleus accumbens drive heroin reinforcement. eLife 7: e39945. doi:10.7554/eLife.39945

Czoty PW, Stoops WW, Rush CR. 2016. Evaluation of the "pipeline" for development of medications for cocaine use disorder: a review of translational preclinical, human laboratory, and clinical trial research. Pharmacol Rev 68: 533-562. doi:10.1124/pr.115.011668

Degenhardt L, Randall D, Hall W, Law M, Butler T, Burns L. 2009. Mortality among clients of a state-wide opioid pharmacotherapy program over 20 years: risk factors and lives saved. Drug Alcohol Depend 105: 9-15. doi:10 .1016/j.drugalcdep.2009.05.021

DeWire SM, Yamashita DS, Rominger DH, Liu G, Cowan CL, Graczyk TM, Chen X-T, Pitis PM, Gotchev D, Yuan C, et al. 2013. A G protein-biased ligand at the $\mu$-opioid receptor is potently analgesic with reduced gastrointestinal and respiratory dysfunction compared with morphine. J Pharmacol Exp Ther 344: 708-717. doi:10 $.1124 /$ jpet.112.201616

de Wit H, Stewart J. 1983. Drug reinstatement of heroinreinforced responding in the rat. Psychopharmacology (Berl) 79: 29-31. doi:10.1007/BF00433012

Di Chiara G, Imperato A. 1988. Drugs abused by humans preferentially increase synaptic dopamine concentrations in the mesolimbic system of freely moving rats. Proc Natl Acad Sci 85: 5274-5278. doi:10.1073/pnas.85.14.5274

Ding H, Czoty PW, Kiguchi N, Cami-Kobeci G, Sukhtankar DD, Nader MA, Husbands SM, Ko M-C. 2016. A novel orvinol analog, BU08028, as a safe opioid analgesic without abuse liability in primates. Proc Natl Acad Sci 113: E5511-E5518. doi:10.1073/pnas.1605295113

Ding H, Kiguchi N, Yasuda D, Daga PR, Polgar WE, Lu JJ, Czoty PW, Kishioka S, Zaveri NT, Ko M-C. 2018. A bifunctional nociceptin and $\mu$ opioid receptor agonist is analgesic without opioid side effects in nonhuman primates. Science Trans Med 10: eaar3483. doi:10.1126/sci translmed.aar3483

Dorn S, Lembo A, Cremonini F. 2014. Opioid-induced bowel dysfunction: epidemiology, pathophysiology, diagnosis and initial therapeutic approach. Am J Gastroenterol Suppl 2: 31-37. doi:10.1038/ajgsup.2014.7

Dowell D, Haegerich TM, Chou R. 2016. CDC guideline for prescribing opioids for chronic pain-United States, 2016. MMWR Recomm Rep 65: 1-49. doi:10.15585/ mmwr.rr6501e1

Evans SM, Foltin RW, Hicks MJ, Rosenberg JB, De BP, Janda KD, Kaminsky SM, Crystal RG. 2016. Efficacy of an adenovirus-based anti-cocaine vaccine to reduce cocaine self-administration and reacquisition using a choice procedure in rhesus macaques. Pharmacol Biochem Behav 150-151: 76-86. doi:10.1016/j.pbb.2016.09.008

Gardner EL. 2011. Addiction and brain reward and antireward pathways. Adv Psychosom Med 30: 22-60. doi:10 $.1159 / 000324065$

Gerber GJ, Bozarth MA, Spindler JE, Wise RA. 1985. Concurrent heroin self-administration and intracranial selfstimulation in rats. Pharmacol Biochem Behav 23: 837842.

Göhler K, Sokolowska M, Schoedel KA, Nemeth R, Kleideiter E, Szeto I, Eerdekens M-H. 2019. Assessment of the abuse potential of cebranopadol in nondependent recreational opioid users: a phase 1 randomized controlled study. J Clin Psychopharmacol 39: 46-56. doi:10 .1097/JCP.0000000000000995

Gold MS, Redmond DE Jr, Kleber HD. 1979. Noradrenergic hyperactivity in opiate withdrawal supported by clonidine reversal of opiate withdrawal. Am J Psychiatry 136: 100102. doi:10.1176/ajp.136.1.100

Gonzalez G, Oliveto A, Kosten TR. 2004. Combating opiate dependence: a comparison among the available pharma- 
cological options. Expert Opin Pharmacother 5: 713-725. doi:10.1517/14656566.5.4.713

Grabowski J, Rhoades H, Silverman P, Schmitz JM, Stotts A, Creson D, Bailey R. 2000. Risperidone for the treatment of cocaine dependence: randomized, double-blind trial. $J$ Clin Psychopharmacol 20: 305-310. doi:10.1097/000 04714-200006000-00003

Greenwald MK, Hursh SR. 2006. Behavioral economic analysis of opioid consumption in heroin-dependent individuals: effects of unit price and pre-session drug supply. Drug Alcohol Depend 85: 35-48.

Greenwald MK, Steinmiller CL. 2009. Behavioral economic analysis of opioid consumption in heroin-dependent individuals: effects of alternative reinforcer magnitude and post-session drug supply. Drug Alcohol Depend 104: 8493.

Greenwald MK, Schuh KJ, Hopper JA, Schuster CR, Johanson C-E. 2002. Effects of buprenorphine sublingual tablet maintenance on opioid drug-seeking behavior by humans. Psychopharmacology (Berl) 160: 344-352. doi:10 .1007/s00213-001-0975-0

Greenwald MK, Johanson C-E, Moody DE, Woods JH, Kilbourn MR, Koeppe RA, Schuster CR, Zubieta J-K. 2003. Effects of buprenorphine maintenance dose on $\mu$-opioid receptor availability, plasma concentrations, and antagonist blockade in heroin-dependent volunteers. Neuropsychopharmacology 28: 2000-2009. doi:10.1038/sj.npp .1300251

Greenwald MK, Comer SD, Fiellin DA. 2014. Buprenorphine maintenance and $\mu$-opioid receptor availability in the treatment of opioid use disorder: implications for clinical use and policy. Drug Alcohol Depend 144: 1-11. doi:10.1016/j.drugalcdep.2014.07.035

Griffiths RR, Wurster RM, Brady JV. 1975. Discrete-trial choice procedure: effects of naloxone and methadone on choice between food and heroin. Pharmacol Rev 27: 357-365.

Griffiths RR, Wurster RM, Brady JV. 1981. Choice between food and heroin: effects of morphine, naloxone, and secobarbital. J Exp Anal Behav 35: 335-351. doi:10.1901/ jeab.1981.35-335

Gunawan T, Tripoli CS, Silberberg A, Kearns DN. 2019 The effect of economy type on heroin and saccharin essential value. Exp Clin Psychopharmacol 27: 598-608. doi:10.1037/pha0000277

Haney M, Spealman R. 2008. Controversies in translational research: drug self-administration. Psychopharmacology (Berl) 199: 403-419. doi:10.1007/s00213-008-1079-x

Haw AJ, Meyer LCR, Greer JJ, Fuller A. 2016. Ampakine CX1942 attenuates opioid-induced respiratory depression and corrects the hypoxaemic effects of etorphine in immobilized goats (Capra hircus). Vet Anaesth Analg 43: 528-538. doi:10.1111/vaa.12358

He S, Li N, Grasing K. 2004. Long-term opiate effects on amphetamine-induced dopamine release in the nucleus accumbens core and conditioned place preference. Pharmacol Biochem Behav 77: 327-335. doi:10.1016/j.pbb .2003 .11 .014

Heyman GM. 2009. Addiction: a disorder of choice. Harvard University Press, Cambridge, MA.

Hofford RS, Chow JJ, Beckmann JS, Bardo MT. 2017. Effects of environmental enrichment on self-administration of the short-acting opioid remifentanil in male rats. Psychopharmacology (Berl) 234: 3499-3506. doi:10.1007/ s00213-017-4734-2

Jarpe MB, Knall C, Mitchell FM, Buhl AM, Duzic E, Johnson GL. 1998. [D-Arg ${ }_{1}, \mathrm{D}-\mathrm{Phe}_{5}, \mathrm{D}-\mathrm{Trp}_{7,9}, \mathrm{Leu}_{11}$ ] substance $\mathrm{P}$ acts as a biased agonist toward neuropeptide and chemokine receptors. J Biol Chem 273: 3097-3104. doi:10.1074/jbc .273.5.3097

Jarvis BP, Holtyn AF, Subramaniam S, Tompkins DA, Oga EA, Bigelow GE, Silverman K. 2018. Extended-release injectable naltrexone for opioid use disorder: a systematic review. Addiction 113: 1188-1209. doi:10.1111/add .14180

Jarvis BP, Holtyn AF, DeFulio A, Koffarnus MN, Leoutsakos J-MS, Umbricht A, Fingerhood M, Bigelow GE, Silverman K. 2019. The effects of extended-release injectable naltrexone and incentives for opiate abstinence in heroindependent adults in a model therapeutic workplace: a randomized trial. Drug Alcohol Depend 197: 220-227. doi:10.1016/j.drugalcdep.2018.12.026

Jasinski DR, Johnson RE, Kocher TR. 1985. Clonidine in morphine withdrawal: differential effects on signs and symptoms. Arch Gen Psychiatry 42: 1063-1066. doi:10 .1001/archpsyc.1985.01790340041006

Johanson CE, Balster RL. 1978. A summary of the results of a drug self-administration study using substitution procedures in rhesus monkeys. Bull Narc 30: 43-54.

John WS, Newman AH, Nader MA. 2015. Differential effects of the dopamine D3 receptor antagonist PG01037 on cocaine and methamphetamine self-administration in rhesus monkeys. Neuropharmacology 92: 34-43. doi:10 .1016/j.neuropharm.2014.12.024

Johnson SW, North RA. 1992. Opioids excite dopamine neurons by hyperpolarization of local interneurons. $J$ Neurosci 12: 483-488. doi:10.1523/jneurosci.12-02-00 483.1992

Kantak KM, Collins SL, Lipman EG, Bond J, Giovanoni K, Fox BS. 2000. Evaluation of anti-cocaine antibodies and a cocaine vaccine in a rat self-administration model. Psychopharmacology (Berl) 148: 251-262. doi:10.1007/ s002130050049

Kantak KM, Collins SL, Bond J, Fox BS. 2001. Time course of changes in cocaine self-administration behavior in rats during immunization with the cocaine vaccine IPC1010. Psychopharmacology (Berl) 153: 334-340. doi:10 $.1007 / \mathrm{s} 002130000555$

Karila L, Marillier M, Chaumette B, Billieux J, Franchitto N, Benyamina A. 2019. New synthetic opioids: part of a new addiction landscape. Neurosci Biobehav Rev 106: 133140. doi:10.1016/j.neubiorev.2018.06.010

Katz JL. 1989. Drugs as reinforcers: pharmacological and behavioural factors. In The neuropharmacological basis of reward (ed. Liebman JM, Cooper SJ), pp. 164-213. Clarendon Press, Oxford.

Kenakin T. 1995. Agonist-receptor efficacy. II: agonist trafficking of receptor signals. Trend Pharmacol Sci 16: 232238. doi:10.1016/S0165-6147(00)89032-X

Kenakin T. 2015. The effective application of biased signaling to new drug discovery. Mol Pharm 88: 1055-1061. doi:10.1124/mol.115.099770

King T, Vera-Portocarrero L, Gutierrez T, Vanderah TW, Dussor G, Lai J, Fields HL, Porreca F. 2009. Unmasking 
E.A. Townsend et al.

the tonic-aversive state in neuropathic pain. Nat Neurosci 12: 1364-1366. doi:10.1038/nn.2407

Klimas J, Gorfinkel L, Giacomuzzi SM, Ruckes C, Socías ME, Fairbairn N, Wood E. 2019. Slow release oral morphine versus methadone for the treatment of opioid use disorder. BMJ Open 9: e025799. doi:10.1136/bmjopen-2018025799

Koch ED, Kapanadze S, Eerdekens M-H, Kralidis G, Létal J, Sabatschus I, Ahmedzai SH. 2019. Cebranopadol, a novel first-in-class analgesic drug candidate: first experience with cancer-related pain for up to 26 weeks. J Pain Symptom Manag 58: 390-399. doi:10.1016/j.jpainsymman .2019.05.012

Koob GF. 2019. Neurobiology of opioid addiction: opponent process, hyperkatifeia, and negative reinforcement. Biol Psychiatry. doi:10/1016/j.biopsych.2019.05.023

Kosten TR, Domingo CB, Shorter D, Orson F, Green C, Somoza E, Sekerka R, Levin FR, Mariani JJ, Stitzer M, et al. 2014. Vaccine for cocaine dependence: a randomized double-blind placebo-controlled efficacy trial. Drug Alcohol Depend 140: 42-47. doi:10.1016/j.drugalcdep.2014.04 .003

Kowalczyk WJ, Phillips KA, Jobes ML, Kennedy AP, Ghitza UE, Agage DA, Schmittner JP, Epstein DH, Preston KL. 2015. Clonidine maintenance prolongs opioid abstinence and decouples stress from craving in daily life: a randomized controlled trial with ecological momentary assessment. Am J Psychiatry 172: 760-767. doi:10.1176/appi .ajp.2014.14081014

Kreek MJ, Borg L, Ducat E, Ray B. 2010. Pharmacotherapy in the treatment of addiction: methadone. J Addict Dis 29: 200-216. doi:10.1080/10550881003684798

Lacy RT, Strickland JC, Feinstein MA, Robinson AM, Smith MA. 2016. The effects of sex, estrous cycle, and social contact on cocaine and heroin self-administration in rats. Psychopharmacology (Berl) 233: 3201-3210. doi:10 .1007/s00213-016-4368-9

Lane JR, May LT, Parton RG, Sexton PM, Christopoulos A. 2017. A kinetic view of GPCR allostery and biased agonism. Nat Chem Biol 13: 929-937. doi:10.1038/nchembio .2431

Lee MC, Wagner HN Jr, Tanada S, Frost JJ, Bice AN, Dannals RF. 1988. Duration of occupancy of opiate receptors by naltrexone. J Nucl Med 29: 1207-1211.

Lenoir M, Cantin L, Vanhille N, Serre F, Ahmed SH. 2013. Extended heroin access increases heroin choices over a potent nondrug alternative. Neuropsychopharmacology 38: 1209-1220. doi:10.1038/npp.2013.17

Lile JA, Stoops WW, Rush CR, Negus SS, Glaser PEA, Hatton KW, Hays LR. 2016. Development of a translational model to screen medications for cocaine use disorder. II choice between intravenous cocaine and money in humans. Drug Alcohol Depend 165: 111-119. doi:10.1016/j .drugalcdep.2016.05.022

Ling W, Amass L, Shoptaw S, Annon JJ, Hillhouse M, Babcock D, Brigham G, Harrer J, Reid M, Muir J, et al. 2005. A multi-center randomized trial of buprenorphine-naloxone versus clonidine for opioid, detoxification: findings from the National Institute on Drug Abuse Clinical Trials Network. Addiction 100: 1090-1100. doi:10.1111/j.13600443.2005.01154.x
Linz K, Christoph T, Tzschentke TM, Koch T, Schiene K, Gautrois M, Schröder W, Kögel BY, Beier H, Englberger W, et al. 2014. Cebranopadol: a novel potent analgesic nociceptin/orphanin FQ peptide and opioid receptor agonist. J Pharmacol Exp Ther 349: 535-548. doi:10.1124/ jpet.114.213694

Logrip ML, Koob GF, Zorrilla EP. 2011. Role of corticotropin-releasing factor in drug addiction: potential for pharmacological intervention. CNS Drugs 25: 271-287. doi:10 $.2165 / 11587790-000000000-00000$

Lyden J, Binswanger IA. 2019. The United States opioid epidemic. Semin Perinatol 43: 123-131. doi:10.1053/j .semperi.2019.01.001

Maguire DR, Gerak LR, Woods JH, Husbands SM, Disney A, France CP. 2019. Long-lasting effects of methocinnamox on opioid self-administration in rhesus monkeys. J Pharmacol Exp Ther 368: 88-99. doi:10.1124/jpet.118.252353

Mattick RP, Breen C, Kimber J, Davoli M. 2014. Buprenorphine maintenance versus placebo or methadone maintenance for opioid dependence. Cochrane Database Syst Rev 2004: CD002207.

Melichar JK, Hume SP, Williams TM, Daglish MRC, Taylor LG, Ahmad R, Malizia AL, Brooks DJ, Myles JS, LingfordHughes A, et al. 2005. Using $\left[{ }^{11} \mathrm{C}\right]$ diprenorphine to image opioid receptor occupancy by methadone in opioid addiction: clinical and preclinical studies. J Pharmacol Exp Ther 312: 309-315. doi:10.1124/jpet.104.072686

Mello NK, Negus SS. 1996. Preclinical evaluation of pharmacotherapies for treatment of cocaine and opioid abuse using drug self-administration procedures. Neuropsychopharmacology 14: 375-424. doi:10.1016/0893-133X(95) 00274-H

Mello NK, Mendelson JH, Kuehnle JC. 1982. Buprenorphine effects on human heroin self-administration: an operant analysis. J Pharmacol Exp Ther 223: 30-39.

Metz VE, Jones JD, Manubay J, Sullivan MA, Mogali S, Segoshi A, Madera G, Johnson KW, Comer SD. 2017 Effects of ibudilast on the subjective, reinforcing, and analgesic effects of oxycodone in recently detoxified adults with opioid dependence. Neuropsychopharmacology 42: 1825-1832.

Morabbi M-J, Razaghi E, Moazen-Zadeh E, Safi-Aghdam H, Zarrindast MR, Vousoghi N, Akhondzadeh S. 2018. Pexacerfont as a CRF1 antagonist for the treatment of withdrawal symptoms in men with heroin/methamphetamine dependence: a randomized, double-blind, placebo-controlled clinical trial. Int Clin Psychopharmacol 33: 111119. doi:10.1097/YIC.0000000000000200

Murphy SM, McCollister KE, Leff JA, Yang X, Jeng PJ, Lee JD, Nunes EV, Novo P, Rotrosen J, Schackman BR. 2019. Cost-effectiveness of buprenorphine-naloxone versus extended-release naltrexone to prevent opioid relapse. Ann Intern Med 170: 90-98. doi:10.7326/M18-0227

Nader MA, Woolverton WL. 1992. Effects of increasing response requirement on choice between cocaine and food in rhesus monkeys. Psychopharmacology (Berl) 108: 295300. doi:10.1007/BF02245115

Negus SS. 2003. Rapid assessment of choice between cocaine and food in rhesus monkeys: effects of environmental manipulations and treatment with $d$-amphetamine and flupenthixol. Neuropsychopharmacology 28: 919-931. doi:10.1038/sj.npp.1300096 
Negus SS. 2006. Choice between heroin and food in nondependent and heroin-dependent rhesus monkeys: effects of naloxone, buprenorphine, and methadone. J Pharmacol Exp Ther 317: 711-723. doi:10.1124/jpet.105.095380

Negus SS. 2009. Opioid antagonist effects in animal models related to opioid abuse: drug discrimination and drug self-administration. In Opioid receptors and antagonists: from bench to clinic (ed. Dean R, Bilsky EJ, Negus SS), pp. 221-226. Humana, New York.

Negus SS, Banks ML. 2011. Making the right choice: lessons from drug discrimination for research on drug reinforcement and drug self-administration. In Drug discrimination: applications to medicinal chemistry and drug studies (ed. Glennon RA, Young R), pp. 361-388. Wiley, Hoboken, NJ.

Negus SS, Banks ML. 2013. Medications development for opioid abuse. In Addiction (ed. Pierce RC, Kenny PJ) Cold Spring Harbor Laboratory Press, Cold Spring Harbor, New York.

Negus SS, Banks ML. 2018. Modulation of drug choice by extended drug access and withdrawal in rhesus monkeys: implications for negative reinforcement as a driver of addiction and target for medications development. Pharmacol Biochem Behav 164: 32-39. doi:10.1016/j.pbb.2017.04 .006

Negus SS, Dykstra LA. 1989. Neural substrates of the reinforcing properties of opioid analgesics. In Focus on biochemistry and physiology of substance abuse (ed. Watson RR), pp. 211-242. CRC, Boca Raton, FL.

Negus SS, Rice KC. 2009. Mechanisms of withdrawalassociated increases in heroin self-administration pharmacologic modulation of heroin vs food choice in heroin-dependent rhesus monkeys. Neuropsychopharmacology 34: 899-911. doi:10.1038/npp.2008.127

Negus SS, Woods JH. 1995. Reinforcing effects, discriminative stimulus effects, and physical dependence liability of buprenorphine. In Buprenorphine: combatting drug abuse with a unique opioid (ed. Cowan A, Lewis JW), pp. 71101. Wiley, New York.

Negus SS, Burke TF, Medzihradsky F, Woods JH. 1993. Effects of opioid agonists selective for mu, kappa and delta opioid receptors on schedule-controlled responding in rhesus monkeys: antagonism by quadazocine. J Pharmacol Exp Ther 267: 896-903.

Noble F, Marie N. 2019. Management of opioid addiction with opioid substitution treatments: beyond methadone and buprenorphine. Front Psychiatry 9: 742. doi:10.3389/ fpsyt.2018.00742

Nunes EV, Bisaga A, Krupitsky E, Nangia N, Silverman BL, Akerman SC, Sullivan MA. 2019. Opioid use and dropout from extended-release naltrexone in a controlled trial: implications for mechanism. Addiction doi:10.1111/add .14735

O'Connor EC, Chapman K, Butler P, Mead AN. 2011. The predictive validity of the rat self-administration model for abuse liability. Neurosci Biobehav Rev 35: 912-938. doi:10 .1016/j.neubiorev.2010.10.012

Panchal SJ, Müller-Schwefe P, Wurzelmann JI. 2007. Opioid-induced bowel dysfunction: prevalence, pathophysiology and burden. Int J Clin Pract 61: 1181-1187. doi:10 $.1111 / j .1742-1241.2007 .01415 . x$
Panlilio LV, Secci ME, Schindler CW, Bradberry CW. 2017. Choice between delayed food and immediate opioids in rats: treatment effects and individual differences. Psychopharmacology 234: 3361-3373.

Pannemans J, Vanuytsel T, Tack J. 2018. New developments in the treatment of opioid-induced gastrointestinal symptoms. United European Gastroenterol J 6: 1126-1135. doi:10.1177/2050640618796748

Pirtle JL, Hickman MD, Boinpelly VC, Surineni K, Thakur HK, Grasing KW. 2019. The serotonin-2C agonist Lorcaserin delays intravenous choice and modifies the subjective and cardiovascular effects of cocaine: a randomized, controlled human laboratory study. Pharmacol Biochem Behav 180: 52-59. doi:10.1016/j.pbb.2019.02.010

Quelch DR, Katsouri L, Nutt DJ, Parker CA, Tyacke RJ. 2014. Imaging endogenous opioid peptide release with $\left[{ }^{11} \mathrm{C}\right]$ carfentanil and $\left[{ }^{3} \mathrm{H}\right]$ diprenorphine: influence of agonist-induced internalization. J Cereb Blood Flow Metab 34: 1604-1612. doi:10.1038/jcbfm.2014.117

Rahimi-Movaghar A, Gholami J, Amato L, Hoseinie L, Yousefi-Nooraie R, Amin-Esmaeili M. 2018. Pharmacological therapies for management of opium withdrawal. $\mathrm{Co}$ chrane Database Syst Rev 6: CD007522.

Rasmussen K, White DA, Acri JB. 2019. NIDA's medication development priorities in response to the opioid crisis: ten most wanted. Neuropsychopharmacology 44: 657-659. doi:10.1038/s41386-018-0292-5

SAMHSA. 2018. Medications for opioid use disorder. Treatment Improvement Protocol 63, HHS Publication No. (SMA) 18-5063FULLDOC, Rockville, MD.

Schmid CL, Kennedy NM, Ross NC, Lovell KM, Yue Z, Morgenweck J, Cameron MC, Bannister TD, Bohn LM. 2017. Bias factor and therapeutic window correlate to predict safer opioid analgesics. Cell 171: 1165-1175.e13. doi:10.1016/j.cell.2017.10.035

Scholz A, Bothmer J, Kok M, Hoschen K, Daniels S. 2018. Cebranopadol: a novel, first-in-class, strong analgesic: results from a randomized phase IIa clinical trial in postoperative acute pain. Pain Physician 21: E193-E206. doi:10.36076/ppj.2018.3.E193

Schwienteck KL, Blake S, Bremer PT, Poklis JL, Townsend EA, Negus SS, Banks ML. 2019a. Effectiveness and selectivity of a heroin conjugate vaccine to attenuate heroin, 6acetylmorphine, and morphine antinociception in rats: comparison with naltrexone. Drug Alcohol Depend 204: 107501. doi:10.1016/j.drugalcdep.2019.06.006

Schwienteck KL, Faunce KE, Rice KC, Obeng S, Zhang Y, Blough BE, Grim TW, Negus SS, Banks ML. 2019b. Effectiveness comparisons of G-protein biased and unbiased $\mu$ opioid receptor ligands in warm water tail-withdrawal and drug discrimination in male and female rats. Neuropharmacology 150: 200-209. doi:10.1016/j.neu ropharm.2019.01.020

Secci ME, Factor JA, Schindler CW, Panlilio LV. 2016. Choice between delayed food and immediate oxycodone in rats. Psychopharmacology 233: 3977-3989.

Sell SL, France CP. 2002. Cocaine and amphetamine attenuate the discriminative stimulus effects of naltrexone in opioid-dependent rhesus monkeys. J Pharmacol Exp Ther 301: 1103-1110. doi:10.1124/jpet.301.3.1103

Selley DE, Liu Q, Childers SR. 1998. Signal transduction correlates of $\mu$ opioid agonist intrinsic efficacy: re- 
E.A. Townsend et al.

ceptor-stimulated $\left.{ }^{35} \mathrm{~S}\right] \mathrm{GTP} \gamma \mathrm{S}$ binding in mMOR-CHO cells and rat thalamus. J Pharmacol Exp Ther 285: 496505.

Sevarino K, Kosten T. 2007. Naltrexone for initiation and maintenance of opiate abstinence. In Opioid receptors and antagonists: from bench to clinic (ed. Dean R, Bilsky E, Negus S). Humana, New York.

Shaham Y, Rajabi H, Stewart J. 1996. Relapse to heroin-seeking in rats under opioid maintenance: the effects of stress, heroin priming, and withdrawal. J Neurosci 16: 19571963.

Singla N, Minkowitz HS, Soergel DG, Burt DA, Subach RA, Salamea MY, Fossler MJ, Skobieranda F. 2017. A randomized, phase IIb study investigating oliceridine (TRV130), a novel $\mu$-receptor G-protein pathway selective ( $\mu$-GPS) modulator, for the management of moderate to severe acute pain following abdominoplasty. J Pain Res 10: 2413-2424. doi:10.2147/JPR.S137952

Smith MA, Fronk GE, Abel JM, Lacy RT, Bills SE, Lynch WJ. 2018. Resistance exercise decreases heroin self-administration and alters gene expression in the nucleus accumbens of heroin-exposed rats. Psychopharmacology (Berl) 235: 1245-1255. doi:10.1007/s00213-018-4840-9

Soergel DG, Subach RA, Burnham N, Lark MW, James IE, Sadler BM, Skobieranda F, Violin JD, Webster LR. 2014. Biased agonism of the $\mu$-opioid receptor by TRV130 increases analgesia and reduces on-target adverse effects versus morphine: a randomized, double-blind, placebocontrolled, crossover study in healthy volunteers. Pain 155: 1829-1835. doi:10.1016/j.pain.2014.06.011

Sora I, Elmer G, Funada M, Pieper J, Li X-F, Hall FS, Uhl GR. 2001. $\mu$ Opiate receptor gene dose effects on different morphine actions: evidence for differential in vivo $\mu$ receptor reserve. Neuropsychopharmacology 25: 41-54. doi:10.1016/S0893-133X(00)00252-9

Spragg S. 1940. Morphine addiction in chimpanzees. Comp Psychol Mono 15: 5-132.

Sulima A, Jalah R, Antoline JFG, Torres OB, Imler GH, Deschamps JR, Beck Z, Alving CR, Jacobson AE, Rice $\mathrm{KC}$, et al. 2018. A stable heroin analogue that can serve as a vaccine hapten to induce antibodies that block the effects of heroin and its metabolites in rodents and that cross-react immunologically with related drugs of abuse. J Med Chem 61: 329-343. doi:10.1021/acs.jmedchem $.7 \mathrm{~b} 01427$

Sullivan MA, Vosburg SK, Comer SD. 2006. Depot naltrexone: antagonism of the reinforcing, subjective, and physiological effects of heroin. Psychopharmacology (Berl) 189: 37-46. doi:10.1007/s00213-006-0509-x

Tenney RD, Blake S, Bremer PT, Zhou B, Hwang CS, Poklis JL, Janda KD, Banks ML. 2019. Vaccine blunts fentanyl potency in male rhesus monkeys. Neuropharmacology 158: 107730. doi:10.1016/j.neuropharm.2019.107730

Thompson T, Schuster CR. 1964. Morphine self-administration, food-reinforced, and avoidance behaviors in rhesus monkeys. Psychopharmacologia 5: 87-94. doi:10.1007/ BF00413045

Thomsen M, Barrett AC, Negus SS, Caine SB. 2013. Cocaine versus food choice procedure in rats: environmental manipulations and effects of amphetamine. J Exp Anal Behav 99: 211-233. doi:10.1002/jeab.15
Thomsen M, Barrett AC, Butler P, Negus SS, Caine SB. 2017. Effects of acute and chronic treatments with dopamine $\mathrm{D}_{2}$ and $\mathrm{D}_{3}$ receptor ligands on cocaine versus food choice in rats. J Pharmacol Exp Ther 362: 161-176. doi:10.1124/ jpet.117.241141

Townsend EA, Blake S, Faunce KE, Hwang CS, Natori Y, Zhou B, Bremer PT, Janda KD, Banks ML. 2019a. Conjugate vaccine produces long-lasting attenuation of fentanyl vs. food choice and blocks expression of opioid withdrawal-induced increases in fentanyl choice in rats. Neuropsychopharmacology 44: 1681-1689. doi:10.1038/ s41386-019-0385-9

Townsend EA, Negus SS, Caine SB, Thomsen M, Banks ML. 2019b. Sex differences in opioid reinforcement under a fentanyl vs. food choice procedure in rats. Neuropsychopharmacology. doi:10.1038/s41386-019-0356-1

Townsend EA, Negus SS, Poklis JL, Banks ML. 2019c. Lorcaserin maintenance fails to attenuate heroin vs. food chocie in rhesus monkeys. Drug Alcohol Depend doi:10.1101/705020

Tunstall BJ, Vendruscolo LF. 2019. Utility of fentanyl vaccines: unique challenges posed by preventing opioid overdose and treating opioid use disorder. Neuropsychopharmacology 44: 1675-1676. doi:10.1038/s41386-0190418-4

Uritsky TJ. 2019. Methylnaltrexone: peripherally acting mu-opioid receptor antagonist. J Adv Pract Oncol 10: 62-67.

Vaccari M, Franchini G. 2010. Memory T cells in Rhesus macaques. Adv Exp Med Biol 684: 126-144. doi:10.1007/ 978-1-4419-6451-9_10

Venniro M, Zhang M, Caprioli D, Hoots JK, Golden SA, Heins C, Morales M, Epstein DH, Shaham Y. 2018. Volitional social interaction prevents drug addiction in rat models. Nat Neurosci 21: 1520-1529. doi:10.1038/ s41593-018-0246-6

Venniro M, Russell TI, Zhang M, Shaham Y. 2019. Operant social reward decreases incubation of heroin craving in male and female rats. Biol Psychiatry doi:10.1016/j .biopsych.2019.05.018

Wachtel SR, Ortengren A, de Wit H. 2002. The effects of acute haloperidol or risperidone on subjective responses to methamphetamine in healthy volunteers. Drug Alcohol Depend 68: 23-33. doi:10.1016/S0376-8716(02) 00104-7

Wade-Galuska T, Galuska CM, Winger G. 2011. Effects of daily morphine administration and deprivation on choice and demand for remifentanil and cocaine in rhesus monkeys. J Exp Anal Behav 95: 75-89.

Webster LR. 2015. Opioid-induced constipation. Pain Med 16: S16-S21. doi:10.1111/pme.12911

Wee S, Koob GF. 2010. The role of the dynorphin-к opioid system in the reinforcing effects of drugs of abuse. Psychopharmacology (Berl) 210: 121-135. doi:10.1007/ s00213-010-1825-8

Weerts EM, Kim YK, Wand GS, Dannals RF, Lee JS, Frost JJ, McCaul ME. 2008. Differences in $\delta$ - and $\mu$-opioid receptor blockade measured by positron emission tomography in naltrexone-treated recently abstinent alcohol-dependent subjects. Neuropsychopharmacology 33: 653-665. doi:10.1038/sj.npp.1301440 
Williams JT, Christie MJ, Manzoni O. 2001. Cellular and synaptic adaptations mediating opioid dependence. Physiol Rev 81: 299-343. doi:10.1152/physrev.2001.81.1 .299

Willins DL, Meltzer HY. 1998. Serotonin 5-HT2C agonists selectively inhibit morphine-induced dopamine efflux in the nucleus accumbens. Brain Res 781: 291-299. doi:10 .1016/S0006-8993(97)01267-5

Winhusen TM, Kropp F, Lindblad R, Douaihy A, Haynes L, Hodgkins C, Chartier K, Kampman KM, Sharma G, Lewis DF, et al. 2014. Multisite, randomized, doubleblind, placebo-controlled pilot clinical trial to evaluate the efficacy of buspirone as a relapse-prevention treatment for cocaine dependence. J Clin Psychiatry 75: 757764. doi: $10.4088 / J C P .13 \mathrm{~m} 08862$

Wurster RM, Griffiths RR, Findley JD, Brady JV. 1977. Reduction of heroin self-administration in baboons by manipulation of behavioral and pharmacological conditions. Pharmacol Biochem Behav 7: 519-528. doi:10.1016/00913057(77)90248-9
Yanagita T. 1978. Drug dependence studies in laboratory animals. NIDA Res Monogr 19: 179-190.

Young AM, Herling S. 1986. Drugs as reinforcers: studies in laboratory animals. In Behavioral analysis of drug dependence (ed. Goldberg SR, Stolerman IP), pp. 9-67. Academic, Orlando, FL.

Zamarripa A, Edwards SR, Qureshi HN, Yi JN, Blough BE Freeman KB. 2018. The G-protein biased $\mu$-opioid agonist, TRV130, produces reinforcing and antinociceptive effects that are comparable to oxycodone in rats. Drug Alcohol Depend 192: 158-162. doi:10.1016/j.drugalcdep .2018.08.002

Zawilska JB. 2017. An expanding world of novel psychoactive substances: opioids. Front Psychiatry 8: 110. doi:10 $.3389 /$ fpsyt.2017.00110

Zernig G, Lewis JW, Woods JH. 1997. Clocinnamox inhibits the intravenous self-administration of opioid agonists in rhesus monkeys: comparison with effects on opioid agonist-mediated antinociception. Psychopharma cology (Berl) 129: 233-242. doi:10.1007/s00213 0050185 


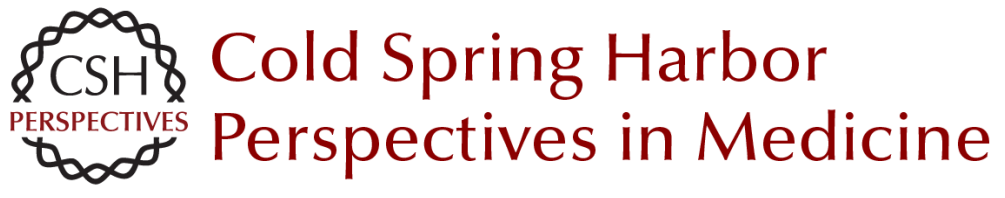

\title{
Medications Development for Treatment of Opioid Use Disorder
}

\author{
E. Andrew Townsend, S. Stevens Negus and Matthew L. Banks
}

Cold Spring Harb Perspect Med 2021; doi: 10.1101/cshperspect.a039263 originally published online January 13, 2020

\section{Subject Collection Addiction}

Developments from Bulk Optogenetics to Single-Cell Strategies to Dissect the Neural Circuits that Underlie Aberrant Motivational States Jose Rodriguez-Romaguera, Vijay M.K. Namboodiri, Marcus L. Basiri, et al.

Consequences of Parental Opioid Exposure on Neurophysiology, Behavior, and Health in the Next Generations

Fair M. Vassoler and Mathieu E. Wimmer

Animal Models of the Behavioral Symptoms of Substance Use Disorders Louk J.M.J. Vanderschuren and Serge H. Ahmed

Translational Research in Nicotine Addiction Miranda L. Fisher, James R. Pauly, Brett Froeliger, et al.

Neonatal Opioid Withdrawal Syndrome (NOWS): A Transgenerational Echo of the Opioid Crisis Andrew E. Weller, Richard C. Crist, Benjamin C. Reiner, et al.

Impairment of Synaptic Plasticity by Cannabis, $\Delta^{\mathbf{9}}$ -THC, and Synthetic Cannabinoids Alexander F. Hoffman, Eun-Kyung Hwang and Carl R. Lupica

Drug-Evoked Synaptic Plasticity of Excitatory Transmission in the Ventral Tegmental Area Camilla Bellone, Michael Loureiro and Christian Lüscher

Opioid-Induced Molecular and Cellular Plasticity of Ventral Tegmental Area Dopamine Neurons Marie A. Doyle and Michelle S. Mazei-Robison
The Persistent Challenge of Developing Addiction Pharmacotherapies

Sarah E. Swinford-Jackson, Charles P. O'Brien,

Paul J. Kenny, et al.

Opioid Modulation of the Gut-Brain Axis in Opioid-Associated Comorbidities

Li Zhang and Sabita Roy

Epigenetics of Drug Addiction Andrew F. Stewart, Sasha L. Fulton and lan Maze

Genetic Vulnerability to Opioid Addiction Brian Reed and Mary Jeanne Kreek

Glutamatergic Systems and Memory Mechanisms

Underlying Opioid Addiction Jasper A. Heinsbroek, Taco J. De Vries and Jamie Peters

Mechanisms of Nicotine Addiction Marina R. Picciotto and Paul J. Kenny

Neural Substrates and Circuits of Drug Addiction Matthew W. Feltenstein, Ronald E. See and Rita A. Fuchs

The Role of the Central Amygdala in Alcohol Dependence Marisa Roberto, Dean Kirson and Sophia Khom

For additional articles in this collection, see http://perspectivesinmedicine.cshlp.org/cgi/collection/ 